\title{
Speech and the Truth-Seeking Value
}

\author{
Brian C. Murchison*
}

\begin{abstract}
Courts in First Amendment cases long have invoked the truth-seeking value of speech, but they rarely probe its meaning or significance, and some ignore it altogether. As new cases implicate questions of truth and falsity, thorough assessment of the value is needed. This Article fills the gap by making three claims. First, interest in truth-seeking has resurfaced in journalism, politics, philosophy, and fiction, converging on a concept of provisional or "functional" truth. Second, the appeal of functional truth for the law may be that it clarifies thinking about a range of human priorities-survival, progress, and character-without insisting on truth in an absolute or transcendent sense. Third, the law's current treatment of truth-seeking in First Amendment cases turns on whether a case implicates the truth of the past, present, or future. Cases about past truth involve its knowability; cases about present truth involve its hiddenness; and cases about future truth involve its falsification. Because judicial treatment of truth-seeking in each of these groupings is underdeveloped, legal thought can benefit from literary works by three major novelists: Paul Scott, author of Staying On; Kazuo Ishiguro, author of Never Let Me Go; and Ian McEwan, author of Atonement. Each of these works clarifies an important aspect of the truth-seeking value of expressive freedoms. The Article concludes by considering the value's limitations, focusing on the complex setting of campaign finance.
\end{abstract}

* Charles S. Rowe Professor of Law, Washington and Lee University School of Law. The author wishes to thank Dean Nora Demleitner for her comments on an earlier draft; Professors Dayo Abah and Toni Locy for helpful conversations on the values of the First Amendment; Cole Wilson for his careful research assistance; and the Frances Lewis Law Center for supporting the project. The Article is dedicated to Ann E. Murchison. 


\section{TABLE OF CONTENTS}

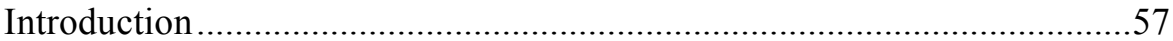

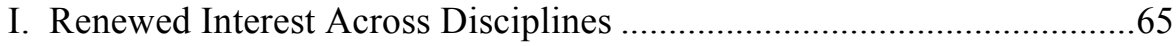

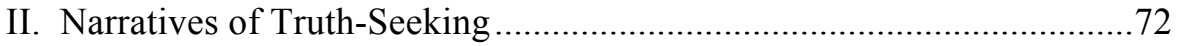

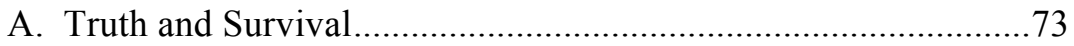

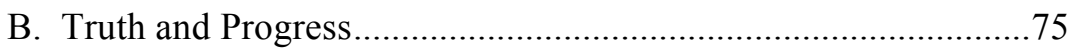

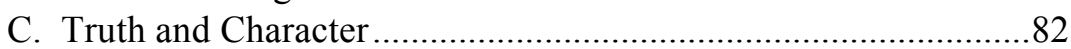

III. Law and the Truth of Past, Present, and Future ...................................86

A. Truth of the Past ........................................................................87

B. Truth of the Present ..............................................................94

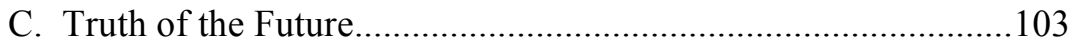

IV. Truth-Seeking and Campaign Finance ..............................................112

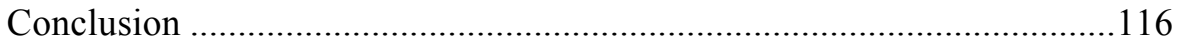




\section{INTRODUCTION}

In the opening decades of the twenty-first century, an arresting but underappreciated development in First Amendment jurisprudence has been the resurfacing of the "truth-seeking" or enlightenment value of the freedoms of speech and press. ${ }^{1}$ This value underlies the familiar metaphor of "the marketplace of ideas," ${ }^{2}$ in which at least two kinds of debates are thought to occur: the first, a clash over facts, specifically over which factual assertions relating to politics, culture, science, or other topics are worthy of belief; and the second, a clash over opinions, specifically over which evaluations of factual assertions are worthy of acceptance and on what basis. ${ }^{3}$ Exploring the layered truth-seeking value from several sides, this Article asks a number of questions. Does the value have more than negligible rhetorical significance in First Amendment contexts? What sorts of cases prompt judges to relate them to a "search for truth"? What do courts find useful in a vocabulary that links speaking to searching, and searching to something that many take to be unsearchable? The Article concludes that while the "search for truth" in the context of First Amendment decisions is related to versions of the concept of "functional truth" found in other contexts-journalism, political theory, philosophy, and works of fiction-its meaning in the law is necessarily its own. ${ }^{4}$

1. See Paul Horwitz, The First Amendment's Epistemological Problem, 87 WASH. L. REV. 445, 446 (2012) (noting increased scholarly attention to "the uneasy role of truth within First Amendment doctrine").

2. "It is the purpose of the First Amendment to preserve an uninhibited marketplace of ideas in which truth will ultimately prevail ...." Red Lion Broadcasting Co. v. F.C.C., 395 U.S. 367, 390 (1969). See also Hustler Magazine, Inc. v. Falwell, 485 U.S. 46, 50-52 (1988) (recognizing the "truthseeking" function of the First Amendment and explaining that self-expression is "essential to the common quest for truth").

3. In a perceptive essay on truth in political life, Jeremy Elkins notes that "a politics of truth need not depend on a claim to possess absolute knowledge of the world or universal laws, but follows simply and directly from the idea that beyond our opinions there lies a world." Jeremy Elkins, Concerning Practices of Truth, in TRUTH AND DEMOCRACY 19, 27 (Jeremy Elkins \& Andrew Norris eds., 2012). Elkins observes that "claims of truth" refer to "one's views about what is and about how things in [the world] are," and that these views "can be subject to evaluations of veracity - not whether they correspond to the world in some naked, noumenal essence, but whether we have good enough reason for accepting them in light of everything we know as well as what we reasonably, under the circumstances, might come to know." Id. "[W]hen those views become the basis for claims on the political community," public debate can encompass not only the factual bases of the claims but also the strengths and weaknesses of the claims themselves. Id.

4. See, e.g., Bill Kovach \& TOM Rosenstiel, The Elements of Journalism 55-56 (3d ed. 2014) (describing journalism as producing "functional truth," defined as "a sorting-out process that takes place between the initial story and the interaction among the public, newsmakers, and journalists"); Joshua Cohen, Truth and Public Reason, in TRUTH AND DEMOCRACY, supra note 3, at 218-20 (advancing a nonmetaphysical "political conception of truth" that "can reasonably be endorsed as common ground for the purposes of consequential collective decisions"); JOHN D. CAPUTO, TRUTH: PHILOSOPHY IN TRANSIT 103-04 (2013) (positing a view of truth as "always a process," marked by "open-endedness and availability to change," including idea of "truth as an event, as something still to be made or done, as what lies ahead, as still in the making, and hence as a promise/risk"); James Wood, The Trick of Truth, NEw RePUBLIC (Mar. 21, 2002) (reviewing IAN MCEWAN, ATONEMENT (2001)) (discussing McEwan's novel as “explicitly troubled by fiction's fictionality—its artificiality—and eager 
The distinctiveness of that meaning lies in its emphasis on "seeking" as an enterprise that is communicative and therefore shared in complex ways. In this sense, the truth-seeking value of speech and press combines notions of both freedom and democratic respect. ${ }^{5}$ Its link to freedom contemplates a dynamic that generously protects a speaker's ability to reach an audience or uncover information in the face of forces that would silence or chill. But the value's grounding in democratic respect is also central: the dynamic is meant to be dialogic in nature and collective in benefit, even if the dialogue is not closely orchestrated and the benefits can be less than immediate. The truth-seeking value prompts a persistent if uneven process of trial and error that, for better or worse, leaves most of the sifting and weighing to citizens themselves.

To be sure, the value has figured prominently in leading cases of other eras. One need only recall the most celebrated moment in "free speech" history: the unexpected self-reversal and invocation of truth-seeking by Justice Oliver Wendell Holmes, Jr., a proud philosophic skeptic in almost every other context. In 1919, Holmes voted to overturn the criminal convictions of socialist and anarchist dissidents who had distributed leaflets opposing deployment of U.S. troops to Russia during World War I. ${ }^{6}$ The leaflets declared capitalism "an enemy of the workers of the world," and accused President Wilson of cowardice for not owning up to U.S. interference with the Russian Revolution. ${ }^{7}$ As Holmes put it, the radicals wanted "to change the mind of the country" by convincing Americans of the "truth" of U.S. dishonesty and greed. ${ }^{8}$ Influenced by young intellectuals who had hammered his earlier votes to sustain similar convictions under the Espionage Act, ${ }^{9}$ Holmes found a First Amendment violation in the convictions of the defendants in Abrams v. United States, whose leaflets he said amounted at best to "puny anonymities." the thought to get itself accepted in the competition of the market," and that "the theory of our Constitution" is that judgments about such statements belonged to

to explore the question of the novel's responsibility to truth").

5. For a compelling meditation on tolerance as "respect," see EVA BRANN, HOMAGE TO americans: Mile-High Meditations, Close Readings, and Time-Spanning Speculations 17 (2010) (defining democratic respect as "a knowledgeable favoritism, open-eyed prejudice for persons and for the most revealing expression of their personhood, namely, their individual humanity: their opinions"). See also Glenn Tinder, Freedom of Expression, The Strange Imperative, 69 YALE REV. 161, $162,167,173$ (1979) (positing that "the crucial mark of respect for a human being is recognizing that he cannot be classified and used but must be encountered and heard," and suggesting that "truth cannot be held by one person alone but is in essence a shared reality." Tinder suggests that truth "is entered into through dialogue, and effective dialogue must be ironic and inconclusive"). Id. at 173.

6. Abrams v. United States, 250 U.S. 616, 624-31 (1919) (Holmes, J., dissenting).

7. Id. at 625 .

8. Id. at 628 .

9. G. EdWard White, Justice Oliver Wendell Holmes: LaW AND the INNER Self 427-28 (1993) (recounting chronology of "the major change in Holmes' attitude toward free speech" in the summer and fall of 1919); THOMAS HEALY, THE GREAT DISSENT 193-97 (2013) (describing impact on Holmes of his friend Harold Laski's difficulties at Harvard University after speaking out publicly in support of a police strike).

10. Abrams, 250 U.S. at 629 (Holmes, J., dissenting). 
citizens, not courts. ${ }^{11}$ A variation on the same theme-that "truth" can be advanced by safeguarding a free flow of information, whether true or false, right or wrong-was voiced decades later when Justice William Brennan, writing for the Supreme Court in New York Times Co. v. Sullivan, asserted that legal protection of at least some false speech about public issues was necessary to minimize the law's chill of truthful expression. ${ }^{12}$ Sullivan's emphasis on creating conditions for uncovering true facts about the pressing problems of American life was contemporaneous with Martin Luther King's Letter from Birmingham Jail, in which King implored the nation to face the "hard, brutal facts" of racial injustice and to "bring [this truth] out in the open, where it [could] be seen and dealt with."13 The two documents-King's Letter and Brennan's opinion for the Court in Sullivan - represented a high-water mark in the legal culture's commitment to protecting speech that discloses, against great odds, the plain face of social fact.

For all their eloquence, Holmes, Brennan, and King were echoing a theme declared on native soil long before any of them lived, indeed long before independence - the 1735 courtroom argument of attorney Andrew Hamilton in his defense of John Peter Zenger, printer of the New-York Weekly Journal. ${ }^{14}$ When Zenger was prosecuted for sedition in New York Colony for printing mocking criticism of a corrupt royal governor, Hamilton demanded the right to defend on the ground of the writing's truth, explicitly invoking the spirit of the Glorious Revolution of 1688 and the strand of Enlightenment thought holding that free articulation of truthful statements about those in power was an essential tool against tyranny. ${ }^{15}$ Even though the colonial court rejected the idea of a defense of truth in sedition cases, the jury acquitted Zenger. In the aftermath, Hamilton's oration was printed and reprinted throughout the colonies, and a new strain of public expression had won a round in the fight for legal legitimacy. ${ }^{16}$

Summarizing two centuries of free speech tradition in this country, Professor Thomas Emerson in 1970 identified the truth-seeking value as a fundamental component of the First Amendment. ${ }^{17}$ "Freedom of expression is an essential process for advancing knowledge and discovering truth," he wrote. "An individual who seeks knowledge and truth must hear all sides of the question, consider all alternatives, test his judgment by exposing it to opposition, and make full use of

11. Id. at 630. For a perceptive reading of Abrams, noting differences between the statutes involved in that case and those in Schenck v. United States, 249 U.S. 47 (1919), see Robert Post, Reconciling Theory and Doctrine in First Amendment Jurisprudence, in ETERNALly VigiLANT: FreE SPEECH IN THE MODERN ERA (Lee C. Bollinger \& Geoffrey R. Stone eds. 2002) 153, 154-61.

12. 376 U.S. 254,279 (1964).

13. Martin Luther King, Letter from Birmingham Jail, reprinted in JONATHAN RIEDER, GOSPEL OF FREEDOM 169, 171, 177 (2013).

14. See generally James AleXander, A Brief NarRative of the CASE AND TRYAL of JohN PETER ZENGER, PRINTER OF THE NEW-YORK WEEKLY JOURNAL (Paul Finkelman ed. 2010) (1736).

15. Id. at 96-97 (quoting Zenger's attorney, Andrew Hamilton).

16. Lincoln Barnett, The Case of John Peter Zenger, AM. HeritAge, Dec. 1971, http:// www.americanheritage.com/content/case-john-peter-zenger [http://perma.cc/CH8S-YVDU].

17. THOMAS I. EMERSON, THE SYSTEM OF FREEDOM OF EXPRESSION 6-7 (1970). 
different minds." ${ }^{\text {E }}$ Emerson's goal was not to defend a philosophical position about the accessibility of "truth" or even to propose a specific theory of truthseeking as a legal idea. Instead, writing in broad strokes, Emerson spoke of truthseeking in a way that had particular resonance in 1970, a time of active conflict in America over civil rights and the Vietnam War, when the need for nonironic devotion to pursuing "political truth" was absolutely compelling.

Yet, despite these instances in which the truth-seeking value commanded center stage in speech disputes, courts in more recent decades have seldom invoked the value in more than a perfunctory way. Even when they have referred to it, they have rarely paused over its meaning or relevance. ${ }^{19}$ Courts have preferred to invoke other recognized First Amendment values - most often, the self-governance value, which protects expression as the engine of civic participation in a democracy, or the self-realization value, which protects expression for its role in the individual's exercise (or pursuit of) autonomy. ${ }^{20}$ Perhaps ideas of selfgovernance and self-realization are more accessible in meaning or more acceptable in theory than the goal of truth-seeking, which may strike a contemporary jurist as abstract, arrogant, illusory, or antidemocratic. Or perhaps contemporary jurists believe that the self-governance and self-realization values are specifications of a broader value associated with truth-seeking, and that tracing the link is unnecessary. Whatever the reason, the absence of a strongly enunciated truthseeking value may be at least partially responsible for the strange results in a host of contemporary cases in which a clear commitment of that kind might have made a difference. ${ }^{21}$

In those cases, courts struggled towards unsatisfying outcomes in cases involving statements that were either factually true or could easily have been seen as nonfactual expressions of opinion. Thus, in Hatfill v. New York Times Co., a suspect in the 2001 anthrax killings was able to entangle the Times in libel litigation for five years, even though the op-ed columns at issue pointedly refrained from accusing him of a crime and stated accurate facts as a basis for urging the FBI to investigate the man aggressively. ${ }^{22}$ The truth-seeking value appeared powerless

18. Id.

19. Professor Horwitz observes that " $[\mathrm{w}]$ here deep questions about the nature of truth and falsity are concerned, courts will rely on general statements and incompletely theorized agreements and leave the theorizing to others." Horwitz, supra note 1, at 488.

20. See Brian C. Murchison, Speech and the Self-Realization Value, 33 HARV. C.R.-C.L. L. REV. 443 (1998); Brian C. Murchison, Speech and the Self-Governance Value, 14 WM \& MARY BILL RTS. J. 1251 (2006). For a discerning study of "free speech theory at the second-order level," see R. George Wright, Dominance and Diversity: A Risk-Reduction Approach to Free Speech Law, 34 VAL. U. L. REV. 1 (1999).

21. Professor Schauer has complained that the free speech tradition "has essentially nothing to say" about the "widespread existence of public falsity." Frederick Schauer, Facts and the First Amendment, 57 UCLA L. REV. 897, 912 (2009). The present Article attempts to give a fresh look at what the courts have assumed and written about questions of truth and falsity and to explore the implications of the courts' statements and silences.

22. 416 F.3d 320 (4th Cir. 2005). Here, an appellate panel reversed the district court's 2004 grant of a motion to dismiss. The panel ruled that op-ed columns in the Times could be found to have 
to protect the Times from years of litigation about whether it was accusing the plaintiff of a crime, and if so, whether it knew the accusation was false or doubted its truth. ${ }^{23}$ A sturdier background understanding of the truth-seeking value surely could have made a difference. In another case, Noonan v. Staples, Inc., a corporate executive sent emails to his staff that accurately stated that an employee had been fired for violating company policy. ${ }^{24}$ Yet the emails became the basis of a libel action that survived summary judgment in federal district court and survived appellate review as well. ${ }^{25}$ Again, the truth-seeking value went unrecognized, incapable of disposing the case at the outset. In still another case, Salzano v. North Jersey Media Group, Inc., the fair report privilege failed to protect a newspaper that had published an article truthfully reporting the contents of a complaint that had been filed in a bankruptcy proceeding. ${ }^{26}$ The article repeated the complaint's allegations of wrongdoing by the plaintiff. The state court of appeals showed no reluctance to affirm precedent that truthful reporting of a filed complaint fell outside of the privilege of fair report. ${ }^{27}$ Although the state's high court ultimately ruled for the newspaper and changed the rule, the result came far too late in the day. ${ }^{28}$ The absence of a clearly stated truth-seeking value arguably contributed to the courts' remarkable missteps in these cases.

In contrast, other recent cases do invoke the truth-seeking value and demonstrate its tantalizing depth, scope, and vitality. The discussions in those cases provide partial scaffolding for this Article's reconsideration of the value's history, purpose, and potential. Although the value's effect in these cases is at best uncertain, the

defamed the plaintiff by imputing to him the murders of five people who were exposed to the anthrax letters. Id. at 331. In a dissent from the Fourth Circuit's denial of a petition for rehearing en banc, Judge Wilkinson argued strongly that the Times "was simply doing its job"- that is, "urg[ing] the investigation of an undeniable public threat," while "expressly avoid[ing] premature accusation" of the plaintiff." Hatfill v. N.Y. Times Co., 427 F.3d 253, 256-57, 259 (4th Cir. 2005) (Wilkinson, J., dissenting).

23. Summary judgment for the New York Times was finally granted in 2007 and was affirmed in mid-2008. Hatfill v. N.Y. Times Co., 532 F.3d 312, 315 (4th Cir. 2008).

24. 556 F.3d 20 (1st Cir. 2009). Here, state law provided that "even a true statement can form the basis of a libel action if the plaintiff proves that the defendant acted with 'actual malice." Id. at 28. The rule came from a 1902 state statute.

25. The panel noted that truth was indeed a defense in cases involving matters of public concern, but declined to consider the constitutional question in the present case, which was considered to involve a matter of private concern. Id. at $28 \mathrm{n}$.7. The court's reason was that the issue had not been briefed at trial or "developed" on appeal. Id. On a petition for rehearing en banc, the First Circuit refused to reach any question of the First Amendment. The court's reason was that the issue was not "so clear that the panel should have acted sua sponte" to strike down the 1902 statute. Hatfill v. N.Y. Times Co., 561 F.3d 4, 6 (1st Cir. 2009). In addition, the court declined to certify the question to the state's high court. Id. at 7 .

26. 993 A.2d 778 (N.J. 2010).

27. "Although the panel [of the middle-level court] concluded that the report was a full, fair, and accurate report of the bankruptcy complaint, it recognized the initial pleadings exception and declared that the fair-report privilege did not apply." Id. at 784.

28. The court held that "the public policy underpinning of the fair-report privilege — advancement of the public's interest in the free flow of information about official actions-would be thwarted by the recognition of the initial pleadings exception." Id. at 791. 
decisions are notable for the breadth of First Amendment issues they consciously link to the truth-seeking value: whether to recognize a common-law privilege for news reporters subpoenaed to a grand jury; whether to uphold a statute criminalizing false claims of receiving military honors; and whether to uphold a "buffer zone" law preventing sidewalk conversations between prolife "counselors" and those entering the premises of an abortion provider.

In the first case, In re Grand Jury Subpoena, Judith Miller, Judge David S. Tatel of the U.S. Court of Appeals for the D.C. Circuit cited the truth-seeking value of the press as a strong reason to recognize a common-law privilege protecting the identity of a journalist's source even in the context of a grand jury subpoena, on the theory that the privilege would promote the "free flow of information" to citizens. ${ }^{29}$ Judge Tatel, who concurred in the panel's judgment that the journalist must testify, broadly defined the truth-seeking function as "exposing corruption among public officers and employees and generally informing the citizenry of public events and occurrences." " Implicit in this discussion was a belief that although the "flow of information" made possible by the privilege over time would probably include true as well as false information, the true information, either in amount or significance, would justify the privilege by assisting citizens in making sense of current affairs and in formulating political opinions. Although the two other judges on the panel declined to join Judge Tatel's analysis ${ }^{31}$ they did not repudiate his discussion of the truth-seeking value, and indeed, his approach has informed the thinking of other judges as well as legislative drafts of a federal shield law. ${ }^{32}$ At the very least, Judge Tatel's linkage of truth-seeking to the concept of privilege in the grand jury context usefully identifies the value's ultimate objective: facilitating an increased "flow of information" to citizens engaged in evaluation of a range of political issues.

In the second case, United States v. Alvarez, a plurality of Justices focused not so much on the desired flow of information as on the proper locus of determination of information's truth or falsity, in this case facts about the receipt of military honors. ${ }^{33}$ The Stolen Valor Act made it a crime to lie about receiving such honors, even with no showing that the lie was told to defame a third party or to obtain financial gain. ${ }^{34}$ The Supreme Court struck down the relevant provision of the Act,

29. 438 F.3d 1141, 1169 (D.C. Cir. 2006) (Tatel, J., concurring).

30. Id. at 1163 (citing Estes v. Texas, 381 U.S. 532, 539 (1965)).

31. Compare Branzburg v. Hayes, 408 U.S. 665 (1972), with In re Grand Jury Subpoena, 438 F.3d at 1147, 1154. Judge Henderson's position was that Branzburg had not addressed the matter of common-law privilege, but that, even if a common-law privilege applied, the government's evidentiary showing outweighed it. $I d$. at 1159 .

32. See N.Y. Times Co. v. Gonzales, 459 F.3d 160, 181, 185-86 (2d Cir. 2006) (Sack, J., dissenting) (approving Judge Tatel's approach); Lee v. Dep't of Justice, 413 F.3d 53 (D.C. Cir. 2005), reh'g en banc denied, 428 F.3d 299, 302-03 (D.C. Cir. 2005) (Garland, J., dissenting). See also Free Flow of Information Act of 2013, https://www.govtrack.us/congress/bills/113/s987/ [http://perma.cc/QL3V-9PUP] (proposing federal shield law incorporating balancing test in several contexts).

33. 132 S. Ct. 2537, 2543 (2012)

34. Id. at 2543 . 
with four Justices relying on the truth-seeking value to protect the false speech in question. ${ }^{35}$ Those Justices-Kennedy, Roberts, Ginsberg, and Sotomayorintimated that assessing the truth or falsity of such claims belongs to citizens, not to single-issue tribunals set up by the government. ${ }^{36}$ The plurality feared that sustaining the Act would allow Congress to create a phalanx of Orwellian "Ministr[ies] of Truth" to decide the simple truth or falsity of other claims, and that such laws could lead over time to a chilling of speech. ${ }^{37}$ A much less intrusive method of settling factual questions about military honors would be the creation of a government website naming all legitimate recipients. ${ }^{38}$ Accordingly, these Justices insisted that "the remedy for speech that is false is speech that is true," and that "[t]he response to the unreasoned is the rational; to the uninformed, the enlightened; to the straight-out lie, the simple truth." 39 Nevertheless, as in the reporter's privilege case, the emphasis in Alvarez on truth-seeking as a First Amendment value did not command a majority, perhaps because the meaning and implications of the value had been unclear.

Alvarez informed the decision of the U.S. Court of Appeals for the Eighth Circuit in 281 Care Committee v. Arneson, where the court examined the constitutionality of a state law criminalizing knowingly false statements about ballot initiatives and erecting an administrative and judicial process for adjudicating allegations of falsity. ${ }^{40}$ The court found that anti-falsity legislation of this kind would only "open the door" to abuse: the law made it too easy for "anyone" to level a charge of falsity and thus trigger the statutory legal process, disrupting and likely chilling public discourse in the process. ${ }^{41}$ The court wrote that "the citizenry, not the government, should be the monitor of falseness in the political arena," and, quoting Supreme Court precedent, added that "once they have done so, it is for them to decide what is responsible, what is valuable, and what is truth." ${ }^{42}$ In another case striking down an anti-falsity state election law, a federal district court signaled the complexity of the citizenry's task, writing that "ultimately, whether or not it is possible to create a system by which impartial citizens could identify lies from truth is unclear."

In a third case, McCullen v. Coakley, a majority of the Court (the Chief Justice and the left-leaning Justices) did coalesce around the truth-seeking value, at least to

35. Id. at 2551 (plurality) (concluding that "the Stolen Valor Act infringes upon speech protected by the First Amendment"); Id. at 2556 (Breyer, J., and Sotomayor, J., concurring); Id. at 2547-48 (plurality) (rejecting "broad censorial power unprecedented in the Court's cases or in our constitutional tradition"); $I d$. at 2550 (citing Holmes's assertion that "the best test of truth is the power of the thought to get itself accepted in the competition of the market").

36. Id. at 2547.

37. Id.

38. Id. at 2551

39. Id. at 2550 .

40. 766 F.3d 774 (8th Cir. 2014), cert. denied, 135 S. Ct. 1550 (2015).

41. Id. at 796,792 .

42. Id. at 796 (quoting McIntyre v. Ohio Elections Comm'n, 514 U.S. 334, 348 n.11 (1995)).

43. Susan B. Anthony List v. Ohio Elections Comm'n, 45 F. Supp. 3d 765, 779 (S.D. Ohio 2014). 
the extent of invoking it to begin analysis of state legislation mandating a wide buffer zone for abortion clinics. ${ }^{44}$ If Judith Miller involved the what of the truthseeking value in the sense of a general objective (i.e., the goal of facilitating a flow of public information), and if Alvarez focused on who, in the sense of identifying the appropriate "judge" of a particular truth question (i.e., citizens rather than a tribunal), McCullen dealt with an aspect of the how of truth-seeking, in the sense of reflecting on a manner-or temper-of speech concerning an exceptionally sensitive public issue and involving not a question of fact but of conscience. Was the opinion itself-in which the temperature of the abortion debate was arguably lowered in finding that the statute at issue was content-neutral — a sign that Justices of dissimilar philosophies can occasionally find a mode of shared thinking, even in highly polarized contexts? McCullen involved a state law that sought to protect public safety and patient access to healthcare by prohibiting pedestrians from knowingly standing on a public way or sidewalk within thirty-five feet of an abortion-providing clinic. $^{45}$ Pro-life plaintiffs argued that the buffer zone precluded them from engaging in their intended mode of speech, which was "sidewalk counseling," rather than what the Court termed "shouting or brandishing signs" or engaging in other forms of "vociferous" protest. ${ }^{46}$ The Court prefaced its discussion by referring to the truth-seeking value of speech, noting that a "virtue" of "traditional public fora"-streets and sidewalks - was that they allow actual face-to-face contact between speakers and other citizens. ${ }^{47}$ That sort of communicative immediacy is simply not possible with print media, websites, or television. ${ }^{48}$ In striking down the statute, the Justices made no claim that "truth" of facts or opinions would suddenly emerge from a sidewalk exchange between strangers. Nor was there any suggestion that truth-seeking itself could easily take place on such an issue in such a place. Yet the Justices' mention of the mode and location of communication in conjunction with their reference to the marketplace of ideas did suggest something else about the truth-seeking value: that, in cases involving efforts at moral suasion, the value embraces an idea that progress towards truth is made possible by respectful exchange-even in the face of strong difference about what conscience requires. In 2010, sounding a similar theme in a case concerning freedom of speech and association in state law schools, Justice Kennedy wrote "that a view's validity should be tested through free and open discussion," and that a "vibrant dialogue is not possible if students wall themselves off from opposing points of view." 49 Again, the idea was that truth-seeking, at least in settings not dominated by factual questions, counsels against self-isolation

44. 134 S. Ct. 2518, 2529 (2014) (referring to the First Amendment's "purpose 'to preserve an uninhibited marketplace of ideas in which truth will ultimately prevail'") (citation omitted).

45. Id. at 2525 .

46. Id. at $2527,2537$.

47. Id. at 2529 .

48. Id.

49. Christian Legal Soc'y Chapter of U.C. Hastings v. Martinez, 561 U.S. 661, 706 (2010) (Kennedy, J., concurring). 
and urges interaction and exchange. But more from the Justices in these cases was not forthcoming.

This Article argues that a clearer understanding of the truth-seeking value is possible, that it can and should be brought to light, and that it should enter the courts' calculations in a range of speech cases. The argument is not that this value should take precedence in all cases, but that it plays a more explicit and careful part in the conversation. Part I of the Article shows that the newer traces of legal interest in this value are matched by commentaries in other disciplines, noting that the concept of truth, at least as properly understood, merits fresh regard and explication. Part II then delves into several narratives of truth-seeking in order to ask why the value has such staying power. Finding that the concept of a "search for truth" has a surprisingly complex pedigree, Part II explores narratives of security, political enlightenment, and virtue, and finds that the "search for truth" as an organizing trope is able to address human ingenuity, struggle, tragedy, and wisdom. The trope's richness in these narratives, allowing oscillations between a focus on "truth" as knowledge prized by society, and a focus on "seeking" as the individual's activity of trial and error in developing moral awareness, may help explain its survival in contemporary consciousness. Part III of the Article turns to the truth-seeking value in legal disputes over the freedom of speech and press. It finds that courts approach truth in different ways, depending on whether the case concerns truth about the past, the present, or the future. The temporality of a given case's truth issue has much to do with the courts' perception of its utility, and the latter perception informs the creation and application of legal doctrine. At the same time, pragmatic courts are reluctant to dig deeply in examining truth-seeking through speech. Part III draws on recent works of fiction-by Booker Prizewinning authors Paul Scott, Kazuo Ishiguro, and Ian McEwan - to fill some of the gaps in the law's justifications. Part IV closes the analysis by considering the truth-seeking value of the First Amendment in perhaps its most difficult contemporary setting - the world of money and politics in Citizens United v. Federal Election Commission. ${ }^{50}$

\section{RENEWED INTEREST ACROSS DISCIPLINES}

The inconclusive references to truth-seeking in the cases mentioned in the Introduction-where truth-seeking was either ignored or invoked with emphasis but little elaboration - might signal that this value has little actual resonance today. Some might even ask whether truth-seeking should remain on the list of First Amendment values at all. Is it still worthwhile to talk of truth-seeking as a function of constitutional negative liberty in a period in which "appeals to truth, whether made by powerful public figures or in ordinary private disagreements" are often greeted with cynicism? ${ }^{51}$ In The Concept of Truth, Richard Campbell notes several

50. 558 U.S. 310 (2010).

51. RiCHARD CAMPBELL, THE CONCEPT OF TRUTH 1 (2011). 
commonplace causes of "deep and pervasive disillusion" about truth: high-profile deceptions by those in public life, exaggerated advertising of consumer products, and perceived bias of mass media in reporting news. ${ }^{52}$ Other factors add to the public's fading faith in truth: accounts of eyewitnesses and experts alike are often proven mistaken and even the hard sciences are "riven by deep theoretical inconsistencies." 53 Campbell notes too that our "trouble with truth" extends beyond mere facts: as communications technologies increase our exposures to other cultures and ways of living, the validity of moral truths "claimed by particular cultural traditions" become more and more suspect. ${ }^{54}$ Political theorist Stephen White similarly notes the passing of unquestioned claims about the world, human nature, and the existence of God, and replacement of these certainties by "weak ontologies" that take "all fundamental conceptualizations of self, other, and world" to be "contestable." 55

A preliminary question, then, is whether a truth-seeking value of speech and press should matter at all. While some scholars credit truth-seeking as the First Amendment's "dominant value" expressive freedom, others see it as an exhausted holdover from the Enlightenment, at best a remnant of belief in the power of discussion and debate to increase human knowledge. ${ }^{58}$ The search for truth, according to some, has little strength in a virtually unregulated media market where, even with the Internet, competing points of view seldom interact. ${ }^{59}$ And even if the truth-seeking had a stable core of meaning, the First Amendment has been "toothless to deal with the problem of public factual falsity." 60

Yet the vocabulary of truth-seeking, however qualified, persists in U.S. thought. As one commentator has put it, American journalism and other "practical professions and crafts" can be considered "spheres of pragmatic truth." ${ }^{\prime \prime}$ As members of a "craft dedicated to the rapid ascertainment of facts," journalists track "what is happening" but operate under inherent limitations of accepted rituals: "their knowledge and vantage point [are] necessarily limited; they have to triangulate within hours; deadlines always loom"; and they follow a "creed" which

52. Id. at $2-3$.

53. $I d$. at 2 .

54. Id.

55. Steven K. White, Sustaining Affirmation: The Strengths Of Weak Ontology In POLITICAL THEORY 8 (2000).

56. LeE C. Bollinger, THE TOLERANT SOCIETY 45 (1986) (stating that "[t]hrough the process of open discussion we find out what we ourselves think and are then able to compare that with what others think on the same issues. The end result of this process, we hope, is that we will arrive at as close to an approximation of the truth as we can.").

57. William P. Marshall, In Defense of the Search for Truth as a First Amendment Justification, 30 GA. L. REV. 1, 1 (1995).

58. Schauer, supra note 21, at 909.

59. James A. Gardner, Anonymity and Democratic Citizenship, 19 WM. \& MARY BILL RTS. J. 927, 945 (2011).

60. Schauer, supra note 21, at 918.

61. HOWARD GARDNER, TRUTH, BEAUTY, AND GOODNESS REFRAMED 27 (2011). 
requires a process of research, investigation, writing, editing, publishing, and correcting error. ${ }^{62}$ The process and creed enable journalists to declare that the "first obligation" and "first principle" of their profession is the "disinterested pursuit of truth," even if it is a "functional truth" involving two distinct tasks: "getting the facts straight," on the one hand, and "making sense of the facts," on the other. ${ }^{63}$ The first concerns accuracy, the second acknowledges the role of interpretation. One journalism textbook portrays news coverage of events as a "continuing journey toward understanding - that begins with the first account of an event and builds over time." $" 64$

In a 2007 book, Journalism and Truth, Tom Goldstein, former dean of the Columbia Journalism School, insists on the staying power of this sort of journalistic truth-seeking and unpacks more of its complexity. He notes that early twentiethcentury reporters, following Walter Lippmann, began subscribing to norms of accuracy and objectivity almost precisely when "intellectuals and artists were moving away from objectivity." 65 In exploring "how journalists think about the idea of truth and how close they come to attaining it," Goldstein acknowledges that the profession's norms of accuracy and objectivity are less exacting than those of the scientific method and historical research, and he urges journalists to "refine their techniques by learning and appreciating how people in other disciplines go about their work." have prevented some of the glaring journalistic misses of recent times, such as the erroneous attribution of combat heroics to Army private Jessica Lynch in the Iraq war, the mistaken reporting of widespread child rapes and other lurid violence in New Orleans after Hurricane Katrina, and the factual errors published in the immediate aftermath of the school shootings in Newtown, Connecticut. ${ }^{67}$ But Goldstein's interest in journalistic truth ranges beyond a concern about rushed or careless reporting. For example, he has no patience for attempts to justify literally untrue news stories on the ground that they serve some "larger" or "essential" truth. ${ }^{68}$ At the same time, he disparages examples of "literal" truth, such as reporter Judith Miller's series in the New York Times on weapons of mass destruction in the lead-up to the U.S. invasion of Iraq. Although Miller's articles may have accurately reported that highly-placed U.S. officials believed that the weapons existed in Iraq, Goldstein argues that reporters should be more than mere

62. Id. at 30,27 .

63. KOVACH \& ROSENSTIEL, supra note 4 , at 49, 55-57.

64. Id. at 57 .

65. TOM GOLDSTEIN, JouRnalism AND TRUTH: StRANGE BEDFELlOWS 37 (2007)

66. Id. at $1,17$.

67. W. Joseph CAmpbell, Getting It Wrong: Ten of the Greatest MisReported Stories IN AMERICAN JouRNALISM 144-62 (Lynch coverage), 163-83 (Katrina coverage). David Folkenflik, Coverage Rapid, and Often Wrong, in Tragedy's Early Hours, NATIONAL PUBLIC RADIO (Dec. 18, 2012 4:26 AM), http://www.npr.org/2012/12/18/167466320/coverage-rapid-and-often-wrong-in-tragedyearly-hours (describing errors in the wake of Newtown shootings).

68. GOLDSTEIN, JOURNALISM AND TRUTH, supra note 65 , at 10-13. 
conduits for reporting what officials believe or what sources disclose. ${ }^{69}$

Goldstein therefore would probably have approved the cautious steps of the New York Times in 2010 when Julian Assange shared with the Times half a million leaked military dispatches from the wars in Iraq and Afghanistan. As Times executive editor Bill Keller wrote, the newspaper's position was that it had "an enormous moral and ethical obligation to use the material responsibly," and its reporters combed through the documents, assessed them to the extent possible for authenticity, "excise[d] material that could put lives at risk," and provided context in articles based on the documents. ${ }^{70}$ For Keller, journalistic truth involves more than transparency. It is "pragmatic" in the sense of faithful to a conscious process of sifting and selection of material based on norms of credibility, reasonable time constraints, and a purpose to avoid causing needless harm. ${ }^{71}$

Another press commentator, Mitchell Stephens of New York University's School of Journalism, links the idea of "pragmatic truth" to a post-modernist sensibility that "currently seems inescapable in journalism."72 Stephens declares that "[w]e are all postmodern now," in the sense of acknowledging the impossibility of perfect or even near-perfect objectivity in describing the world or recording its events. ${ }^{73}$ At the same time, Stephens cautions journalists against convincing themselves "that, since everything comes down to interpretation anyway, there is no point in digging deeper." " Perhaps referring to Miller's WMD series, Stephens insists that reporters must "move beyond spin to what is, to use a possibly out of date word, really happening." 75 They must "still provide their audiences with as much of the information needed to make a judgment as possible," and "they should take their audiences as close as possible to truth.", Stephens uses "truth" without embarrassment. In a guide for prospective court reporters, one author (a former journalist) writes, "For me the process of verification was constant: I reached out to as many people as I could, given the constraints of a deadline, to check what I had heard. I repeatedly asked myself, who else would know if this were true?"77

A credo of this kind may describe at least a portion of "citizen journalism," whose practitioners are engaged in everything from electronic news coverage to attention-grabbing rants and self-disclosures. Scholars tracking the rise and influence of bloggers have tried to nail down the role, if any, of a truth-seeking value in cyberspace. According to Professor Jane Singer, bloggers "do not see

69. Id. at 57-61.

70. Bill Keller, Dealing with Assange and the WikiLeaks Secrets, N.Y. TiMES, Jan. 26, 2011, at MM32, http://www.nytimes.com/2011/01/30/magazine/30Wikileaks-t.html.

71. Id. at 13-17.

72. Mitchell Stephens, We're All Postmodern Now, 44 Colum. Journalism ReV. 60, 63, July/ Aug. 2005.

73. Id. at 61

74. Id.

75. Id. at 68 .

76. Id. at 69 .

77. TONI LOCY, COVERING AMERICA'S COURTS: A ClASH OF RigHTS 9 (2013). 
truth as resting on the decision of one autonomous individual or group of individuals within a news organization or anywhere else. ${ }^{78}$ Instead, bloggers see truth as emerging from shared, collective knowledge-from an electronically enabled marketplace of ideas. $" 79$

The late British philosopher Bernard Williams likely would have approved this guardedly persistent use of the vocabulary of truth among journalists. Williams did not espouse a view that one could find an independent-of-self standpoint from which to see and know the world, but in his final book, Truth and Truthfulness, he shrewdly noted that "two currents of ideas are very prominent in modern thought": on the one hand, "an intense commitment to truthfulness - or at any rate, a pervasive suspiciousness, a readiness against being fooled, an eagerness to see through appearances to the real structures and motives that lie behind them," and on the other hand, "an equally pervasive suspicion about truth itself: whether there is such a thing; if there is, whether it can be more than relative or subjective or something of that kind; altogether, whether we should bother about it, in carrying out our activities or in giving an account of them." 80 Williams shared the latter suspicions. Although he thought that objective truths were possible in physical science (at least in narrow, specific ways), such truths were not possible in ethics. ${ }^{81}$ For Williams, ethical truths were "relative to culture." 82 But he also stressed the "commonsense" notion of "everyday truths," which he wrote "can readily and reasonably be counted as facts." 83 Williams took pains to recall that Frederic Nietzsche, who in one place defined truth as "a movable host of metaphors, metonymies, and anthropomorphisms," elsewhere accepted that "there are facts to be respected," praised the ancients for their "sense for facts, the last-developed and most valuable of all the senses," and wrote that English psychologists were brave creatures "who have been taught to sacrifice desirability to truth, every truth, even a plain, bitter, ugly, foul, unchristian, immoral truth-Because there are such truths." ${ }^{\circ 4}$ Williams was interested in truth less as a philosophical "than as a politically salient idea," and his book detailed what he called "the values of truth": sincerity, which he defined as honest representation of the self, and accuracy, which he defined as avoidance of "wishful thinking or intellectual laziness." $85 \mathrm{He}$ insisted that these virtues were essential to political liberalism, especially to the protection of the weak from the powerful. This he called "the anti-tyranny

78. Jane Singer, Contested Autonomy: Professional and Popular Claims on Journalistic Norms, 8 JOURNALISM STUDIES 79, 85 (2007).

79. Id.

80. Bernard Williams, TRUTH AND TRUTHFulNESS: AN ESSAY IN GENEALOGY 1 (2002).

81. William Greenway, Modern Metaphysics, Dangerous Truth, Post-Moral Ethics: The Revealing Vision of Bernard Williams, 51 PHILOSOPHY TODAY 137, 139-40 (2007).

82. Id. at 140 .

83. WILLIAMS, supra note 80 , at 10 .

84. Id. at 16,145 .

85. Matthew Sleat, On the Relationship between Truth and Liberal Politics, 50 INQUIRY 288, 291-92 (2006). 
argument" for the virtues of truth. ${ }^{86}$ Williams went so far as to insist that the virtues of truthfulness had intrinsic rather than merely instrumental value. And he maintained that grasping these virtues as intrinsic would be essential as Western culture awakes to a "totally disenchanted, completely de-Platonized intellectual world., 87

Williams stood at a distance from Richard Rorty, who advocated "dropping the idea of truth," which he saw as a "God surrogate" and thus an "unprofitable topic." 88 Rorty's goal was to "scrub away the illusions and myths that cling" to the old concept of truth. ${ }^{89}$ Like Williams, Rorty claimed Nietzsche as a guide, but he did so for the view that "we would be stronger, freer, better human beings if we could bring ourselves to dispense with all such surrogates." 90 The "search for truth" was best thought of as "a particular species of the search for happiness." 91 For Rorty, the moral virtues of "truthfulness, sincerity, exactness, and trust" did not depend on any concept of truth, but could exist readily enough "by reference to our practices of justification." ${ }^{92}$ Rorty stressed that a different vocabulary-such as that provided by the language of practical reason, rather than by assertions about "reality" - provided a more "desirable self-image" for human beings and would lead to less oppressive social dynamics. ${ }^{93}$ Several commentators believe that Williams had the better of the argument, one maintaining that for purposes of the antityranny argument, the truth vocabulary advocated by Williams was less subject to manipulation than the truth-eschewing justifications of Rorty, ${ }^{94}$ another arguing that Rorty's arguments may be right that we lack a "substantive theoretical account" of knowledge but wrong for denying even "humdrum truths of common sense (we might even say, of sanity) that express the reality of our world and our everyday knowledge of it." ${ }^{95}$ Eugene Garver expresses a Rortyan view when he writes that the "success of liberal democracy depends on lowering one's ambitions from seeking truth to settling for agreement." $" 96$

86. WILLIAMS, supra note 80, at 207.

87. Richard Rorty, To the Sunlit Uplands, LONDON REVIEW OF BOOKS, Oct. 31, 2002 (reviewing BERNARD WILLIAMS, TRUTH AND TRUTHFULNESS (2002)).

88. RiCHARD RORTY, CONTINGENCY, IRONY, AND SOLIDARITY 8 (1989); RICHARD RORTY \& PASCAL ENGEL, What's THE USE OF TRUTH? 40 (2007).

89. RORTY \& ENGEL supra note 89, at 11 (statement of Pascal Engel, characterizing Rorty's thought).

90. Rorty, supra note 87 , at 14.

91. Id. at $13-14$.

92. RORTY \& ENGEL, supra note 89 , at 42.

93. Rorty, supra note 87 , at 9.

94. Sleat, supra note 85, at 294 (crediting Williams's "political objections to Rorty's wholesale rejection of the realist vocabulary of truth" on the ground of Rorty's failure "to distinguish between beliefs that have been influenced or manipulated by the use of political power and those that have not").

95. Gary Gutting, Rorty's Critique of Epistemology, in RICHARD RORTY 58 (Charles Guignon \& David R. Hiley eds., 2003).

96. Eugene Garver, For the Sake of Argument: Practical Reasoning, Character, and THE Ethics of Belief 14 (2004). See also Benjamin R. Barber, Misreading Democracy: Peter Euben and the Gorgias, in Demokratia: A CONVERSATION On Democracies ANCIENT AND Modern 364 (Josiah Ober \& Charles Hedrick eds. 1996) (arguing that "democratic politics is not the least interested 
The Williams-Rorty exchange prompts the question: Is democracy incompatible with the "search for truth"? Michael Lynch protests the view that "the proper response to skeptical arguments [about truth] is to acknowledge the groundlessness of our believing, roll up our sleeves, and go on from there." 97 For Lynch, truth has a place in politics, and the relation stems from a vision of equality. Lynch bases his alternative approach on a conception of liberal democracy, defined in part as "the fundamental social practice of not simply acting, but of acting in concert with one another." 98 Action of this kind entails discussion of issues and claims, and disagreement among citizens is inevitable. How is disagreement to be handled? The answer begins with the recognition of a central democratic ideal: Citizens are "rational, autonomous agents worthy of equal respect under the law" and "capable of making judgments about what one ought to believe." 99 When agents disagree, democratic respect requires a practice of giving reasons for positions and decisions and taking care not to usurp the decision-making of others. On this view, democracy is "a space of reasons," and it is here that Lynch brings truth into the analysis. ${ }^{100}$ By "space of reasons," he means that citizens, wherever possible, should justify their positions by explaining why they think one view of relevant facts is closer to the truth than another. On this view, giving truth-aiming reasons respects the autonomy of fellow citizens and amounts to the best "common currency" for political argumentation. ${ }^{101}$ Rorty and others would argue that such reason-giving should be based on what can produce consensus- - "principles we can all accept"- and should not be linked to potentially divisive, disrespecting claims of truth. ${ }^{102}$ But Lynch makes a strong case that truth-aiming reasons do not violate democratic respect: "[T]he common reasons we all do recognize as reasons are reasons for thinking that some belief is true." 103 Lynch maintains that "aiming at the truth in political argument" is not only consistent with, but required by, the Rawlsian "principle of toleration," which Lynch argues does not preclude truthaiming arguments—although, practically speaking, it might well "limit the stock [of truth-aiming reasons] from which we draw." 104

While the Williams-Rorty-Lynch debate continues in philosophical precincts, political theory is showing its own renewed interest in the connection, if any, of truth to politics. A recent compilation of trenchant essays, Truth and Democracy,

in truth. It is not discourse on the way to truth, but discourse as a substitute for truth, discourse in the absence of truth, discourse as an endless voyage that must chart direction without the aid of known destinations").

97. Michael P. Lynch, Democracy as a Space of Reasons, in TRUTH AND DEMOCRACY 115, supra note 3.

98. David Couzens Hoy, On Truth and Democracy: Hermeneutic Responses, in TRUTH AND DEMOCRACY, supra note 3, at 150 (reviewing Michael P. Lynch essay).

99. Lynch, supra note 97, at 118.

100. Lynch, supra note 97, at 116.

101. Lynch, supra note 97, at 118, 120-21.

102. Lynch, supra note 97, at 120 (discussing Rawlsian political theory).

103. Lynch, supra note 97, at 120.

104. Lynch, supra note 97 , at 120. 
reflects that interest. Backing Williams's insistence on preserving the role of truth, Jeremy Elkins and Andrew Norris situate the discussion in the world of what they call "real politics," involving debates about what the facts involved in a particular issue are and how they should be evaluated. ${ }^{105}$ "It is hard to maintain," they write, "that it makes no difference how attentive we are to the specific conditions of the world that we seek to affect, or that the quality of the decisions that we make is wholly unrelated to the strength of the evidence behind them and the care of the analysis underlying them." "106 They point out that, although "there will obviously always be differences of judgment-about the evidence itself, about what to do about it, and so on - even with respect to the political-philosophical differences that come into play, most will believe that at least their own views are based on truthful (if contested) propositions about the world." 107 These theorists acknowledge the possibilities that truth-aiming arguments can make consensus difficult and at the same time can thwart a "healthy dissensus" (by bringing "a history of metaphysical baggage" and the specter of "political domination"). ${ }^{108}$ But they posit that "a serious engagement with the problems of social life cannot do without questions of truth; that questions about truth are inevitable in any society that takes politics seriously; and that questions of truth are not adequately resolved by dispensing with them." 109

If nothing else, this summary demonstrates that truth-seeking remains an important if enigmatic component of contemporary thought across disciplines. As such, it provides a backdrop and partial rationale for this Article's consideration of truth-seeking's place in First Amendment jurisprudence. Perhaps the law's reticence to pinpoint the meaning of the truth-seeking value of expressive freedoms has something in common with the ideas summarized above: an awareness of the limitations of strong theories of truth along with a conviction that "functional truth" and truthfulness remain useful, even necessary, concepts.

\section{NARRATIVES OF TRUTH-SEEKING}

If truth and truth-seeking are subjects of renewed interest in the law and across disciplines, a question worthy of further exploration is: why? This Part discusses several narratives that yield unexpectedly complex accounts of the benefits associated with truth-seeking. Some of the narratives focus on virtues that truthseeking affords the seeker, vindicating the practice and showing its centrality to a way of life. Other narratives focus on the political and social effects of truthseeking, most stressing the social "progress" it has enabled. But not all the narratives are vindicatory, some emphasizing its difficulties and tragic excesses.

105. Elkins \& Norris, supra note 3 , at 3.

106. Elkins \& Norris, supra note 3, at 2.

107. Elkins \& Norris, supra note 3, at 2.

108. Elkins \& Norris, supra note 3, at 2.

109. Elkins \& Norris, supra note 3, at 2-3. 


\section{A. Truth And Survival}

In 2006, in a brief meditation entitled On Truth, Harry G. Frankfurt explored reasons for truth's importance. First on the list was "the thought that truth often possesses very considerable practical utility" for societies wishing to "make sufficiently well-informed judgments and decisions concerning the most suitable disposition of its public business." ${ }^{110}$ In broad strokes, Frankfurt pointed out that a society's basic survival could depend on "knowing enough about relevant facts . . . to cope prudently and effectively with its problems." expanded on this idea-the instrumental reasons for truth's centrality-in Truth and Truthfulness. He examined the concepts in his title from the perspective of naturalism, which, according to one of its proponent asks, "How is it that creatures like us, inhabiting the kinds of physical, interpersonal, and cultural environments we do, come to have the values we do ... ?"112 To answer this, he employed the method of genealogy, developing what he called an "imagined developmental story." 113 Williams's premise was that the traditional verities that might be thought to underlie a commitment to truthfulness are no longer available to moderns, and that a naturalistic "developmental" narrative was the only plausible entrée to an understanding of truth's importance. ${ }^{114}$ He began by imagining an "elementary society" - a "state of nature" comprised of a group of human beings whose "basic needs and limitations" included "the need for co-operation." 115 They live in "a small society" and share "a common language, with no elaborate technology and no form of writing." They divide labor, including the pooling of information. ${ }^{116}$ In fact, the group's survival depends on pooling, which Williams says is one of "those objectives [that are] important to almost every human purpose." 117 With survival at stake, certain crucial "dispositions" are therefore encouraged and valued, particularly the two stressed by Williams: accuracy, the quality of taking care in gathering information so that one gets one's beliefs "right," and sincerity, the quality of honesty in communicating what one actually believes the gathered information is. ${ }^{118}$ In Williams's view, "People need to be reliable observers, and other people need to be able to trust what they say." 119 The "virtues of truth" therefore involve resistance to fantasy, wishful thinking, and lies. Williams had much more to say about the virtues of truth, particularly his sense that their value

110. HENRY G. FRANKFURT, ON TRUTH 15-16 (2006).

111. Id. at 16 .

112. MARK JOHNSON, MORALITY FOR HUMANS: ETHICAL UNDERSTANDING FROM THE PerspeCtive of Cognitive SCIENCE 130 (2014). See also Williams, supra note 80.

113. WILLIAMS, supra note 80 , at 21 .

114. WILLIAMS, supra note 80, at 21.

115. BERNARD WILLIAMS, ESSAYS AND REVIEWS 1959-2002 408 (2014); WILLIAMS, supra note 80 , at 38 .

116. WILLIAMS, supra note 80 , at 42 .

117. WILLIAMS, supra note 80, at 41, 43, 57.

118. WILLIAMS, supra note 115 , at 407.

119. Id. at 408 . 
was intrinsic rather than merely instrumental. Those ideas will be explored in Section $\mathrm{C}$ below, under the heading, "Truth and Character."

Frankfurt's and Williams's insights on truth's connection to survival are elaborated in compelling fashion by dystopian literature such as 1984 by George Orwell, in which authoritarian government forbids any questioning of its monstrous orthodoxy. Facts of everyday life are manipulated, changed, or "forgotten" to suit the state's agenda of total control over thought and action. ${ }^{120}$ In such a world, devotion to truth amounts to a desperate hold on sanity itself. ${ }^{121}$ "Truth" in Orwell's story is connected to survival not in the sense of a society's pooling of information to resist threats from the outside, but in the sense of one person's uniting with another to resist threats from the inside-from the state itself. Winston Smith and his lover, Julia, risk everything for moments of truthful interaction: Their honesty with each other permits a precious respite from statemandated falsifications of reality. When they share their beliefs with a third person, a state official, they momentarily rejoice in the occasion to expand their circle of honesty - until they are betrayed. ${ }^{122}$ Orwell traces Winston's subsequent torture and "re-education," which culminates in surrender and a seemingly final acceptance of the regime's declaration that $2+2=5$. Winston "survives" physically, but, as Orwell puts it, a bullet has entered his brain. ${ }^{123}$

There is no shortage of real-life dissidents who invoke truth for its life-and-death relevance. One was Zbigniew Herbert, poet of Polish resistance in the latter half of the twentieth century and witness to Soviet control and its complex, often bitter aftermath. Herbert gave voice to the struggle to speak freely and to sculpt his own vision of civilization, defining his vocation in terms of "reality." He wrote, "The poet's sphere of action, if his attitude toward his work is serious, is not the 'contemporary'-which I take to mean the state of our current knowledge about society, politics, and science- but the real, the stubborn dialogue of man with the concrete reality surrounding him, with this table, with that neighbor, with this time of day: the cultivation of a dwindling capacity for contemplation." 124 A fellow poet, Seamus Heaney, wrote of one of Herbert's books that its "true subject is survival of the valid self, of the city, of the good and the beautiful; or rather the

120. GeORGe ORWELl, 1984 (Signet Classic ed., 1981), at 16 (telescreen carries image of denounced rebel, "sole guardian of truth and sanity in a world of lies"), 32 (state changes facts of the past, such that "if all others accepted the lie which the Party imposed - if all records told the same talethen the lie passed into history and became truth"), 38 ("vaporized" enemies of the state "were therefore considered never to have existed"), 179 ("There was truth and there was untruth, and if you clung to the truth even against the whole world, you were not mad.").

121. WILLIAMS, supra note 80, at 147 (discussing Orwell).

122. ORWELL, supra note 120, at 105 (lovers' embrace was "a blow struck against the Party. It was a political act"), 182-185 (arrest by Thought Police).

123. ORWELL, supra note 120, at 239 (Winston tracing the false equation in dust), 245 (accepting Big Brother).

124. Zbigniew Herbert, quoted in James Marcus, Zbigniew Herbert: An Introduction, WoRDS WITHOUT BORDERS, http://wordswithoutborders.com/dispatches/article/zbigniew-herbert-anintroduction [http://perma.cc/YX73-2W6B]. 
subject is the responsibility of each person to ensure that survival." 125

\section{B. Truth ANd Progress}

A second truth narrative has its origin in the classical Enlightenment, which, whether it was a "philosophical project" or a "social movement," was undoubtedly a "transformative moment in Western history," famously described as "man's release from self-incurred immaturity' through the use of reason." ${ }^{26}$ The Enlightenment narrative has elements of survival through truth, to be sure, but it is primarily a story of going beyond survival and provoking change in political and moral life throughout the West. Capturing the sense of ideas fueling reform, one commentator calls the Enlightenment "an assault on the past in the name of the future." 127 Enlightenment thought, while varied in emphasis and intensity throughout its domain, uniformly focused on the individual's freedom and capacity to search for truth other than the truth of king or church - in effect, to define his or her own existence by thinking and speaking freely with others. ${ }^{128}$ Since for sheer intellectual excitement no other historical period surpasses the classical Enlightenment, the headiness of the period lends itself to the sprawling prose of Anthony Pagden's recent book, The Enlightenment (And Why It Still Matters), in which he writes: "If we regard ourselves as modern, if we are forward-looking, if we are tolerant and generally open-minded, if stem-cell research does not frighten us but fundamentalist religious beliefs do, then we tend to think of ourselves as 'enlightened.' And in thinking this, we are in effect declaring ourselves to be the heirs, however distant, of a particular intellectual and cultural movement [which] has been identified with an exalted view of human rationality and of human benevolence, and with a belief, measured and at time skeptical, in progress and in the general human capacity for self-improvement." 129

The vocabulary of reason in search of truth caught the temper of the classical Enlightenment. As Pagden puts it, the eighteenth-century French philosophers explained themselves as seeking "a truth which was independent of the dogmas of religion, of fundamentals, and of sects." For many thinkers of that period, "it was in the moral constitution of man that one had to seek for the foundations of his obligations, the origin of his ideas about justice and virtue."130 The movement made an imprint not only on ideas but also on a way of life: "Enlightenment reason [grew] out of a commitment to live by the truth."131 The sought-for truth was not the "revealed truth" of the church, which Enlightenment writers scorned as a blend

125. SeAmus HeAney, Finders KeEPers: Selected Prose 1971-2001 182 (2002).

126. DORINDA OUTRAM, THE ENLIGHTENMENT 2 (2013) (quoting Kant).

127. Anthony Pagden, The Enlightenment And Why It Still Matters 14 (2013).

128. Cf. IsAaC KRAMNick, The Portable EnLightenMENT ReAder ix-x (1995) (noting that the "intellectual ferment" of the Enlightenment was "transnational").

129. PAGDEN, supra note 127 , at $1-2$.

130. PAGDEN, supra note 127. at 15 (quoting Condorcet).

131. Steven D. Smith, Recovering (from) Enlightenment?, 41 SAN DIEGO L. REV. 1263, 1269-70 (2004). 
of "superstition, intolerance, and tyranny," but the truth of "cold facts," "the simple truth of things." "132 Making no secret of their "aversion to [religious] hocus-pocus," these thinkers displayed eager skepticism and "engaging cynicism" as they traced the facts of social conditions and the effects of power, freely sharing "youthful blasphemies and talk of hanging the last king in the entrails of the last priest." ${ }^{\prime 133}$ Inspired by Newton's "search into Things themselves," 134 the Enlightenment writers studied human life, its setting and psychology, the individual's connections to the world and to others. They sought "to discover how as a matter of fact the outer world of nature behaved, and what as a matter of fact had occurred in times past." 135 At the core of the search was a belief in progress: "that man by deliberate intention and rational direction can set the terms and indefinitely improve the quality of his mundane existence."136 The Enlightenment writers had a "preoccupation with human welfare," a "penchant for projects," all inspired by an "ideal of service, the humanitarian impulse to set things right." 137 The idea of working in the present for the eventual betterment of mankind was motivated by a sense of duty to "posterity" and faith that posterity would warmly recognize all efforts made. ${ }^{138}$ Their vision was to use mankind's natural faculties "to bring their ideas and their conduct, and hence the institutions by which they lived, into harmony with the universal natural order." 139 In such a climate, new institutions arose "based on the interchange of ideas, rather than to mark or display social and political rank," knowledge was marketed to new and wider audiences, and "public opinion" emerged "as a force to be reckoned with.", 140

Whether the Enlightenment lived up to its visions has been a matter of substantial debate, as has whether it tragically contained the seeds of twentieth and twenty-first century oppressions and despair. Writing in the 1930s and questioning whether French Enlightenment writers had actually "renounced the superstition and hocus-pocus of medieval Christian thought," Carl Becker saw those thinkers as "guilty of massive self-deception." ${ }^{141}$ Their work, he wrote, was simplistically medieval, clinging to the very structures and religious preconceptions that it tried to supersede. To be sure, the French philosophers had rejected "the authority of church and the Bible," Becker noted, "but [they] exhibited a naïve faith in the authority of nature and reason. They scorned metaphysics, but were proud to be

132. CARL L. BeCKer, The HeAvenly City OF the EighteEnth-CENTURy Philosophers 105, 42 (2d ed. 2003).

133. Id. at 31

134. Id. at 58

135. Carl L. Becker, Afterthoughts on Constitutions, in THE CONSTITUTION RECONSIDERED 422 (CONYERS READ, ed. 1968) (rev'd. ed.).

136. Id. at 423.

137. BECKER, supra note 132 , at $40-41,139$.

138. BECKER, supra note 132, at 139.

139. BECKER, supra note 132, at 65 .

140. OUTRAM, supra note 126 , at 25.

141. BECKER, supra note 132, at 29; Smith, supra note 131, at 1268 (summarizing Becker's argument). 
called philosophers .... They defended toleration valiantly but could with difficulty tolerate priests. They denied that miracles ever happened but believed in the perfectibility of the human race." ${ }^{142}$ Were they "at once too credulous and too skeptical"? They may have "demolished the Heavenly City of St. Augustine," but they "rebuil[t] it with more up-to-date materials," creating nothing short of a "religion of humanity." 143 Becker asked how the Enlightenment writers could have looked at "the tangled wilderness of the world in this symmetrical, this obvious and uncomplicated pattern." 144 How could they have missed that "the nature of man was far more perverse, the mind of man far less responsive to rational persuasion and humane impulses" than they supposed? Although the Enlightenment writers had believed in "progressive improvement made by the efforts of successive generations of men," Becker in mid-twentieth century America could see only that "every effort to shape the world of social relations to humane ends by rational means has ended in confusion and defeat." 145 What the Enlightenment had lacked was a tragic sense; its reliance on a vision of "perfectibility" could only lead to disappointment, and worse, violence. For Becker, a modern definition of truth could be no more than this: "the perception of discordant experience pragmatically adjusted for a particular purpose and for the time being." 146

In the seventy years since Becker wrote, other doubts about the Enlightenment have been regularly voiced - not simply that it was over-optimistic about what could be found in the search for truth, or that it was imprisoned in self-defeating language, but that its understanding of truth and truth-seeking lacked a necessary moral dimension. In his study of "Gandhi the Philosopher," Akeel Bilgrami examines that self-styled truth-seeker's own quarrel with the Enlightenment. ${ }^{147}$ Gandhi had "undeniably Enlightenment elements in his thought," Bilgrami acknowledges, "including his humanism and the concern that our moral judgments be relevant to all people." In another sense, however, Gandhi was starkly antiEnlightenment, rejecting its conception that truth was "a cognitive notion," rather than "a moral one." For Gandhi, the "deepest theoretical source" of the Enlightenment's notion of truth was its "scientific outlook," which he thought regarded truth as merely "a property of sentences or propositions that describe the world." 148 Gandhi "recoiled" from that approach because, according to Bilgrami, he believed that it "intellectualize[d]" the individual's relation to society, seeing society "as an object of study, study that makes it alien to our moral experience of it." The cognitive notion of truth embodied the view that "reality [was] something to be mastered and conquered, an attitude that leads directly to the technological frame of mind that governs modern society." That frame of mind, which ignores

142. BECKER, supra note 132, at 30-31.

143. BECKER, supra note 132, at 31, 161.

144. BECKER, supra note 132, at 46.

145. BECKER, supra note 132, at 129; Becker, supra note 135, at 425.

146. Becker, supra note 135 , at 426.

147. AKEEL BilgRAMI, SECUlARISM, IdENTITY, AND ENCHANTMENT 101-21 (2014).

148. Id. at $116-17$. 
"communal localities" where "moral experience" and "practical relations to the world" have the chance to flourish, focuses instead on "increasingly abstract places and structures such as nations and eventually global economies," producing a "moral psychology which ultimately underlies violence in our social relations." "149 In contrast, Gandhi saw truth as moral in the sense of "experiential." On this view, truth could only refer to "moral experience," never to "propositions purporting to describe the world." 150 He therefore omitted descriptions of social conditions from his understanding of truth, and he reserved the concept for evaluations of conditions or moral judgments.

Gandhi actively used the vocabulary of truth: his followers were known as truth-seekers and practiced satyagraha, or "tenacity in the pursuit of truth." 151 But this tenacity had a special meaning. Gandhi's methodology of truth-seeking was to make one's moral judgments clear but to refrain from expressing hostility to opposing judgments. Individuals were to hold their moral values modestly, not to use them as swords or to inflict them as "principles." 152 This no-hostility rule stemmed from a particular conception of moral judgment and its connection to nonviolence. It was Gandhi's view that moral criticism of the views of others could constitute a first step towards violence, and that the better form of moral communication was acting as a moral exemplar, "making visible [a] moral stance." 153

Bilgrami himself cannot quite subscribe to Gandhi's rejection of the cognitive value of truth. He points out that Gandhi left "a great deal out of our normative interest in truth," including "our tendency to think that apart from the moral virtues involving truth (such as truth-telling and living by and exemplifying our moral values) there is also in some sense a value or virtue in getting things right about the world and discovering the general principles that explain its varied phenomena." 154 Bilgrami's analysis forces the question of whether Gandhi exaggerated the failings of Enlightenment thought by defining truth too narrowly, perhaps even over-stating the threat of violence in hostile speech, and thus under-appreciating the workings of politics in getting at truth. ${ }^{155}$

Even accepting the strength of these critiques-Becker's point that Enlightenment thought risked repeating the blindness of the religious thought it hoped to bury, and Gandhi's insistence that truth has to mean more than propositions about the world - the narrative of searching for truth through the "civilizing force" of reason was to ensure progress remains strong in American legal thought. ${ }^{156}$ Two cases, one from the Enlightenment era itself, the other from

149. Id.

150. Id. at 116 .

151. Id. at 105 .

152. Id. at 109 .

153. Id. at $112-15$.

154. Id. at 118 .

155. Id. at 119.

156. AleXANDER M. Bickel, The Supreme Court AND the IdEA of Progress 82 (1978). 
the twentieth century, underscore this strength. The first is the Zenger case of 1735 , mentioned in the Introduction, featuring a closing argument about free speech that illustrates much of the intellectual boldness of the Enlightenment described by Pagden (and none of the flaws that troubled Becker or Gandhi). ${ }^{157}$ Defense attorney Andrew Hamilton's oration is a harbinger of the strength of the American concept of free expression, and his arguments, embodying the spirit of Cato's Letters, show Enlightenment thought in action. ${ }^{158}$ The second is a speech by Associate Justice David H. Souter about Brown v. Board of Education, explaining that monumental decision as an example of "progress" made possible by "facing facts" about society and injustice. ${ }^{159}$

The Zenger case centered around a colonial newspaper's criticisms of a corrupt colonial governor, William Cosbie, appointed by George II to govern New York Colony in the early 1730s. ${ }^{160}$ From the beginning of his tenure, Cosbie had clashed with colonists, who resented his heavy-handed rule, his firing of a prominent judge, and his blatant use of office for personal financial gain. Cosbie's adversaries sought to have him recalled to London and filled the New-York Weekly Journal with unsigned editorial criticism and mockery. They alleged that, under Cosbie's rule, "the law itself [was] at an end" in the colony. According to their bill of particulars, "We see men's deeds destroyed, judges arbitrarily displaced, new courts erected without consent of the legislature by which False . . . trials by juries are taken away when a governor pleases, men of known estates denied their votes contrary to the received practice ...."161 In 1734, Cosbie ordered four editions of the paper to be burned, bypassed the grand jury in charging the newspaper's printer, Zenger, with seditious libel, and jailed Zenger for months before trial. ${ }^{162}$ The case arose some fifty years after the Glorious Revolution of 1688 , a pivotal event in which a king was forced from power and his successors made concessions to Parliament on issues of power and liberty. ${ }^{163}$ The Zenger case implicated a host of questions on the meaning of that liberty: questions concerning the jury's role in a prosecution for criticizing government and questions about the continued

157. A BRIEF NARRATIVE (Paul Finkelman, ed., 2010), supra note 14.

158. Cato's Letters, the works of John Trenchard (1662-1723) and Thomas Gordon (d. 1750), constituted "a searing indictment of eighteenth-century British politics and society written in response to the South Sea Bubble crisis, which appeared first serially in The London Journal and then, beginning in 1720, in book form." BERNARD BAILYN, THE IDEOLOGICAL ORIGINS OF THE AMERICAN REVOLUTION 36 (1967).

159. Justice David H. Souter, Harvard Commencement Remarks, May 27, 2010, http://news.harvard.edu/gazette/story/2010/05/text-of-justice-david-souters-speech [http://perma.cc/D6WJ-DH88].

160. Paul Finkelman, Introduction: Politics, The Press, and the Trial of John Peter Zenger, to A BRIEF NARRATIVE, supra note 14, at 1-7 (Paul Finkelman ed., 2010).

161. A BRIEF NARRATIVE, supra note 14, at 73-74 (quoting criminal "information" containing charges against Zenger) (Hamilton's argument).

162. A BRIEF NARRATIVE, supra note 14, at 73-74 (recounting burning of newspaper and other events leading to trial).

163. KRAMNICK, supra note 128 , at $\mathrm{x}$ (linking beginning of the British Enlightenment to the Glorious Revolution). 
applicability of pre-1688 English precedents in defining sedition and rejecting truth as a defense. Addressing these matters, the argument of defense attorney Andrew Hamilton, which in written form survived the case, allows a close look at colonialera thinking about truth-seeking and its goal of "progress."

Throughout his oration, Hamilton invoked the Enlightenment idea of intellectual progress in various ways. In the face of the oppressive law of seditious libel, with its doctrine rigged against any critic of government, with its enforcement triggered by government "information" rather than by grand jury indictment, and with all but trivial issues to be decided by judges rather than by jury, Hamilton essentially asked for something akin to jury nullification "in the cause of liberty." 164 His other arguments were equally bold, each based on an idea of progress. Thus, he invoked progress that had already occurred in England - the "pulling down" of the Court of Star Chamber-and argued that case precedents from the Star Chamber, which seemed to say that truth was no defense, should no longer be followed, particularly not in a New York colonial courtroom. ${ }^{165}$ "I was in hopes," he argued, "as that terrible Court, where those terrible judgments were given and that law established which [the prosecution] has produced for authorities to support this cause, was long ago laid aside as the most dangerous court to the liberties of the people of England that ever was known in that kingdom .... For it is well known that what would have been judged treason in those days for a man to speak, I think, has since not only been practiced as lawful but the contrary doctrine has been held to be Law."166 In addition, strenuously arguing that a jury should decide Zenger's case on all questions, Hamilton described the duties of a jury in much the way that Enlightenment writers described the broad "duties" of enlightened citizens when any questions of truth arose: "[J]urymen are to see with their own eyes, to hear with their own ears, and to make use of their own consciences and understandings in judging of the lives, liberties or estates of their fellow subjects." $167 \mathrm{He}$ also urged a definition of power wholly consistent with the spirit of the Glorious Revolution, likening power to "a great river, [which] while kept within its due bounds, is both beautiful and useful; but when it overflows its banks, it is then too impetuous to be stemmed, it bears down on all before it, and brings destruction and desolation wherever it comes." 168 Finally, Hamilton argued that some progress that had already occurred with respect to freedom of religion in England-the allowance of open advocacy of diverse religious views - should be matched by respect for freedom of speech in the colonies. He denounced what seemed to be the prosecution's logic, that "in New York a man may make very free with his God, but he must take special care what he says of his governor." 169 Progress in religious freedom made no sense without accompanying progress in political

164. A BRIEF NARRATIVE, supra note 14 , at 111

165. A BRIEF NARRATIVE, supra note 14. at 102.

166. A BRIEF NARRATIVE, supra note 14, at 79.

167. A BRIEF NARRATIVE, supra note 14 , at 105.

168. A BRIEF NARRATIVE, supra note 14, at 110.

169. A BRIEF NARRATIVE, supra note 14, at 99. 
freedom. Urging acquittal, Hamilton concluded by arguing that the newspaper had simply done what natural law and English law allowed: "exposing and opposing arbitrary power False . . . by speaking and writing the truth." 170 By ending his oration on the word "truth," Hamilton made it central to his argument that truthful adversarial response to power was both a right and a duty of citizens, and it seems plain that, for Hamilton, "truth" embraced both cognitive and experiential meanings. He asked the jury to find that certain events had actually occurred and to make, in effect, a moral judgment about a specific clash between rulers and the ruled.

Hamilton's oration, then, embodied Enlightenment values connecting the search for truth to an idea of progress. A modern example of such thought is Justice Souter's 2012 commencement speech at Harvard University, in which he discussed the nature of judging in constitutional law cases, particularly in Brown v. Board of Education. ${ }^{171}$ Souter was responding to social critics who accuse the Supreme Court of activist "lawmaking" and "making up" constitutional rulings, ${ }^{172}$ in this instance Brown's over-turning of Plessy v. Ferguson. ${ }^{173}$ How could "separate but equal" mean one thing in 1896 and something else in 1954? Assuming that the raw factual differences of the two cases - railroad cars in the first, public schools in the second - were not significant, how could the cases come out so differently? Souter argued that the answer was to be found in the cases' highly different historical contexts. In 1896, Justices on the Plessy Court could remember "the day when human slavery was the law in much of the land," so that "the formal equality of an identical railroad car meant progress," whereas in 1954, the Justices looked at "enforced segregation" and saw something that was not only different but intolerable: "a judgment of inherent inferiority on the part of the minority race." 174 Souter's point was that the change in context had coincided with a change in "judicial perception" of the meaning of facts. He added that "judicial perception turns on the experience of the judges and on their ability to think from a point of view different from their own." ${ }^{, 175}$ While Souter did not elaborate on the origins of a change in judicial perception of the meaning of enforced segregation, his implication was that "experience" and the capacity to think from a different perspective relate to the workings of a marketplace of ideas - the discussion of facts and evaluations through words, speeches, articles, art, and other forms of communication. In effect, Souter described a culture of argument and evaluation in which the meaning of social facts can change, leading to reform which some (although rarely all) will identify as "progress." In all of this, we hear echoes of Hamilton orating on the conditions justifying innovation in the law and on the

170. A BRIEF NARRATIVE, supra note 14, at 111.

171. 347 U.S. 483 (1954).

172. Harvard Commencement Remarks, supra note 159, at 2 (noting critics who accuse the Supreme Court of "activism to extend civil liberties").

173. 163 U.S. 537 (1896).

174. Harvard Commencement Remarks, supra note 159, at 8.

175. Harvard Commencement Remarks, supra note 159, at 9-10. 
changing meaning of liberty in the British world after 1688.

Unlike the French philosophers, Souter did not foresee a short- or long-term "new heaven, new earth," nor was his theme the perfectibility of mankind. Souter acknowledged living in "an indeterminate world I cannot control." But he echoed the Enlightenment spirit in saying that "it is still possible to live fully in the trust that a way will be found leading through the uncertain future." And he eloquently concluded, "If we cannot share every intellectual assumption that formed the minds of those who framed the charter, we can still address the constitutional uncertainties the way they must have envisioned, by relying on reason, by respecting all the words the Framers wrote, by facing facts, and by seeking to understand their meaning for living people." ${ }^{, 176}$ In this sober confidence in progress sought by reason, we again hear Hamilton. Most important is Souter's emphasis on "facing facts," by which he implies a commitment to truth, both "cognitive" and "experiential."

\section{Truth AND Character}

A third truth narrative concerns virtues associated with truth and truth-seeking in contemporary life. Frankfurt suggests that a concern for truth allows for humility about our capacities and therefore a modicum of self-definition, based on "recognition that there are facts and truths over which we cannot hope to exercise direct or immediate control."177 The "concept of reality" is "essentially a concept of what limits us, of what we cannot alter . . by the mere movement of will." 178 By appreciating "a world of stubbornly independent reality," individuals "come both to recognize [themselves] as beings distinct from others and to articulate the specific nature of [their] identities." 179 Truth-seeking ironically becomes the path for achievement when individuals see and assess the limits of what is actually possible.

Philosopher-novelist Iris Murdoch thinks that this is easier said than done. In her book of essays, The Sovereignty of Good, Murdoch writes, "In the moral life the enemy is the fat relentless ego." 180 She nods approvingly at Freud's "thoroughly pessimistic view of human nature," seeing "the psyche as an egocentric system of quasi-mechanical energy, largely determined by its own individual history, whose natural attachments are sexual, ambiguous, and hard for the subject to understand or control." 181 On this view, "introspection reveals only the deep tissue of ambivalent motive, and fantasy is a stronger force than reason. Objectivity and unselfishness are not natural to human beings." ${ }^{182}$ Against this

176. Harvard Commencement Remarks, supra note 159 , at 10

177. FRANKFURT, supra note 110, at 100.

178. FRANKFURT, supra note 110 , at 99.

179. FRANKFURT, supra note 110, 100-01.

180. IRIS MURDOCH, THE SOVEREIGNTY OF GOOD 52 (1970).

181. Id. at 51 .

182. Id. 
view, moral philosophy, at least for Murdoch, "is properly ... the discussion of this ego and of the techniques (if any) of its defeat."183 Living in a "world without God," Murdoch seeks a method for "reorientation of an energy that is naturally selfish," and she asks, "What is a good man like? How can we make ourselves morally better? Can we make ourselves morally better?" 184 Goodness for Murdoch relates to "truth-seeking," in the sense of a disciplined attention to the "real," or the "intellectual ability to perceive what is true, which is automatically at the same time a suppression of self." 185 And she stresses that "the direction of attention is, contrary to nature, outward, away from self which reduces all to a false unity, towards the great surprising variety of the world. ${ }^{186}$ As one commentator explains, "Clarity of vision about the real organizes the system of psychic energy, thus enabling the person to choose and to act rightly." 187 Acting rightly, Murdoch suggests, involves an ever-deepening awareness of what is beyond the self and a method of decision-making flowing from that awareness. She seems to have Shakespeare's Lear in mind, in his stripped-down, revelatory experience of the heath, when she writes, "The more the separateness and differentness of other people is realized, and the fact seen that another man has needs and wishes as demanding as one's own, the harder it becomes to treat a person as a thing." 188 So, for Murdoch, the "search for truth" begins an unending process of ordering and clarifying the self; "it can stretch the imagination, enlarge the vision, and strengthen the judgment."189

In her account, the mind's experience of attending to "the real" inevitably involves "rankings or qualitative distinctions of value," thus measuring what is seen against "an implicit ideal of perfection," which Murdoch labels the Good. ${ }^{190}$ She sees "the moral life as a pilgrimage from appearance to reality which is guided by an idea of perfection and a desire for spiritual improvement or change.,"191 Thinkers proposing a naturalistic account, such as Bernard Williams, emphatically desert Murdoch at this point. Williams is interested only in "human attitudes toward the truth" and rejects any outlook that, following Plato, "associates truth and goodness in ways that represent[] these things as altogether prior to a human interest in them." ${ }^{\text {"192 }}$ Williams has no patience for Murdoch's focus on transcendent goodness, her belief in "the Good" as "something inherent in a hard order of

\footnotetext{
183. Id. at 52 .

184. Id. at 54,52 .

185. Id. at $90,65,66$.

186. Id. at 66

187. William Schweiker, The Sovereignty of God's Goodness, in IRIS MURDOCH AND THE SEARCH FOR HUMAN GOODNESS 209, 222 (Maria Antonaccio and William Schweiker eds., 1996).

188. Murdoch, supra note 180 , at 66.

189. Murdoch, supra note 180 , at 90.

190. Maria Antonaccio, Form and Contingency in Iris Murdoch's Ethics, in IRIS MURDOCH AND THE SEARCH FOR HUMAN GOODNESS, supra note 187, at 133.

191. Maria Antonaccio, Form and Contingency in Iris Murdoch's Ethics, in IRIS MURDOCH AND THE SEARCH FOR HUMAN GOODNESS, supra note 187, 129.

192. WilLIAMS, supra note 80 , at 60-61.
} 
reality," or her placement of truth-seeking in such a schema. ${ }^{193}$ Williams simply asks, "What will she say to the claim-a pressing one, after all-that there is no such order of things, that what she would have us yearn for is not there?"194

Both Frankfurt and Murdoch focus on truth's utility for character. Frankfurt stresses the role of truth-seeking in identity formation, and Murdoch ponders the place of truth-seeking in a moral pilgrimage. They both conclude that truth-seeking fosters the virtue of humility - the seeker's gradual sense of proportionality about herself and the place she realistically occupies in the world. Williams's book is ambitious in a different way: going beyond utility, it considers whether the virtues of truth-seeking, which he identifies as accuracy and sincerity, can be seen as having intrinsic value. The answer to this question is central to Williams's urgent concern-namely, the fate of political liberalism in an age in which both Frankfurt's optimism about human perception and Murdoch's search for a supersensible reality may ring hollow for many people. For Williams, the current age is a time of stark anxiety about truth and its necessity in the political order. ${ }^{195}$ As noted earlier, while he sees a sharp social insistence on truthfulness, manifested in efforts to cut through appearances at all levels of politics and social interaction, Williams also finds widespread social distrust for-even contempt of - "truth" as a concept. ${ }^{196}$ In the face of this anxiety, Williams's effort is to make a compelling argument that the virtues of truth-accuracy and sincerity - are intrinsically, and not simply instrumentally, important. The argument is crucial, he thinks, for multiple reasons, primarily to shore up and indeed save political liberalism from the threat of tyranny. ${ }^{197}$ Williams's point is straightforward: political beliefs, pronouncements, and other statements purporting to be factual must answer to a criterion of truth, which Williams defines as the "order of things that is independent of us, where that means, in particular, independent of our will." 198 If that criterion is allowed to atrophy, and the virtues associated with it (dedication to getting things right and disposition not to lie) deteriorate, then the only standard left for evaluating assertions in society will be whatever criterion of "justification" is used by those in power. Or, as one commentator puts the idea: "The political benefit of the realist vocabulary of truth is that it tells us that the justificatory standards of our beliefs are such that they cannot be altered by the use of power. Without this sort of static and unassailable model of justification we invite the possibility that power can bear upon which of our beliefs are true or not. Without reality as the determinate of our beliefs, we invite the possibility that power and the will of others becomes the thing that determines them."199 Against a backdrop of such

193. Williams, supra note 115 , at 144 (reviewing IRIS MURDOCH, THE FIRE AND THE SUN: WHY Plato BANISHED THE ARTISTS).

194. Williams, supra note 115 , at 144.

195. Williams, supra note 80 , at 39.

196. See supra text accompanying note 80 .

197. WILLIAMS, supra note 80, at 207.

198. WILLIAMS, supra note 80, at 140.

199. Sleat, supra note 85, at 298. 
assumptions, Williams memorably concludes, "To the extent that we lose a sense of the value of truth, we shall certainly lose something and may well lose everything." 200

So, while Frankfurt and Murdoch emphasize the virtue of humility in the moral life of the individual, Williams emphasizes the virtues of accuracy and sincerity in the political life of the state. As a result, "Williams is concerned less with truth as a philosophical than as a politically salient idea." 201 Writing from the standpoint of naturalism, Williams insists that "everyday truths" do exist, that society has a strong conviction that truthfulness about non-trivial factual questions matters, and that, more generally, an essential project for Western thought is to "revalue" its virtues for a post-Enlightenment age. ${ }^{202}$ Williams therefore writes from an internal standpoint, and his terminology, e.g., knowledge, the virtues of truth, plain truths, everyday truths, facts, and so forth, "must be understood intra-culturally."203 For him, "only the sphere of the physical is ontologically ultimate"; the sphere of mind is not, although civil society can and does reach its own situated conclusions about facts and values. ${ }^{204}$ The driving force of Truth and Truthfulness is Williams's concern that society's internal understanding and respect for factual truthfulness are at risk and must not be allowed to fade. Williams therefore examines the function of truth through a vindicatory genealogy — not as a "platonically other-worldly idea," but as one "in relation to very basic needs," and then pursues its significance, if any, beyond mere function. ${ }^{205}$ Intellectual transformation is essential: the values may collapse without their old foundations. To create a "post moral ethic," according to Williams, society must reaffirm the importance of factual truth and see that truthfulness applies as well to "care in arriving at moral attitudes and honesty in expressing such attitudes."206

Truth-seeking, then, can affect character in multiple ways. Moral philosophers who address individual development emphasize the suppression of self that accompanies truth-seeking and the salutary development of humility. Political theorists stress civic virtues - accuracy and sincerity-and consider their importance for liberal self-rule. For all their differences, Frankfurt, Murdoch, and Williams share a largely unspoken appreciation of one other virtue-courage. The individual's capacity for the stamina and daring necessary to look towards a reality beyond the self and to make positive use of that looking-beyond, imperfect as the vision may be, is an assumption of their works.

200. WILLIAMS, supra note 80 , at 7.

201. Sleat, supra note 85 , at 291.

202. Greenway, supra note 81 , at 143,147

203. Greenway, supra note 81 , at 143 .

204. Greenway, supra note 81 , at 143.

205. WILLIAMS, supra note 80, at 32-36.

206. Colin McGinn, Isn't It the Truth?, New York ReVIEW OF BoOKS, Apr. 10, 2003, at 72 (reviewing BERNARD WILlIAMS, TRUTH AND TRUTHFULNESS (2003)). 


\section{LAW AND THE TRUTH OF PAST, PRESENT, AND FUTURE}

Part III examines the treatment of truth in a number of American legal decisions involving the Speech and Press Clauses of the First Amendment. As mentioned earlier, the Supreme Court has not provided significant guidance on the truthseeking value, and it would be wrong to argue that a comprehensive approach exists. At best, legal scholarship can suggest a way to think about existing law and the assumptions that appear to drive the decisions. This Part argues that U.S. decisions divide analytically into three main groups, depending on whether the facts at issue concern the past, present, or future. Each temporal grouping reflects its own view of the nature and value of the truth involved, the strength of competing interests, and the content of applicable legal doctrine.

A breakdown of the cases along temporal lines is suggested not only by the focus of the cases themselves but also by analogy to the work of various authorities on truth-seeking. Thus, as discussed earlier, Carl Becker discussed classical Enlightenment thought in terms of its often distinctive conceptions of past, present, and future. For the figures studied by Becker, the past was an age of manipulated truth, illusions created or fortified by popes and kings; the present was a time of "simple truth" unveiled by scientists and an array of seekers from other realms of thought; and the future would be the occasion for further progress, even if unsteady or temporarily thwarted. ${ }^{207}$ Williams, too, thought in temporal terms: the value of truth to an imagined community of the past, the anxiety about truth among today's conflicted heirs of the Enlightenment, and the concretizing of truth as an intrinsic value tomorrow. ${ }^{208}$ When courts have considered truth-seeking, they too seem to be aided by a vocabulary of past, present, and future. As argued here, that vocabulary enables courts to consider truth in usefully different facets-past truth as evidence of how a current social issue arose and evolved; present truth as voice articulating a social fact happening now; and future truth as flow of hoped-for information that society will need to solve its problems.

This Part therefore examines three categories. The first category is comprised of cases concerning the use of the past to shed light on the present. The cases involve writings that use individual lives to illustrate social problems. Underlying the cases is often a question of the "knowability" of the past: how accurate are the accounts of past lives, especially when they are pressed into service to represent a social phenomenon? Are there dangers of claiming too much - or understanding too little-about the facts of past lives? The question is vexing, particularly when raised by individuals who say that they have been trivialized or misrepresented by such accounts, even if for a worthy cause. But the alternative may be worse-if

207. BECKER, supra note 132, at 123 (explaining that "the task of the [eighteenth-century] Philosophers was to present another interpretation of the past, the present and the future state of mankind").

208. WiLLIAMS, supra note 80, at 41-43 (presenting the "developmental" story of truth-sharing in the state of nature); 39 (noting the "anxiety" of the present regarding truth); 59 (asserting that the future will require more than "a purely instrumental conception of the values of truth"). 
past lives are off limits to social commentators, and the immediacy and impact of their narratives are lost, important discussion of social issues would surely deteriorate, perhaps vanish. This Part's discussion of a modern novel that addresses the issue, Paul Scott's Staying On, deepens the analysis and suggests a solution.

The second category is comprised of cases concerning truth in the present. The cases involve efforts by citizens or media to ferret out information from a powerful entity, usually a government or a corporation, and the sought-after information often consists of the powerful entity's own words. Public exposure of this language is seen as an indispensable tool of democratic accountability. The response of the government or corporation is to do everything possible to silence the citizen or journalist, and so the underlying issue is not the knowability of truth but its hiddenness. This Part's analysis includes reference to a second modern novel, Kazuo Ishiguro's Never Let Me Go, which explores how the hiddenness of truth can affect the individual's relation to self, others, and the world.

The third category is comprised of cases concerning truth in the future. These cases involve the workings of the common-law libel tort and statutory actions for false statements in various contexts. Underlying these cases is a concern not with the knowability of truth or the hiddenness of truth but with its falsification. The courts proceed by asking how to ensure a future flow of truthful speech overall. In striking down or modifying rules based on that concern, courts ironically show a high tolerance for falsity. Their theory is that protecting some false speech is necessary in order to facilitate a flow of communication that will include an acceptably high content of truthful speech overall. Rules that condone truth's coexistence with significant amounts of falsity in public discourse are surely controversial. A third modern novel, Ian McEwan's Atonement, suggests a way of thinking about this complex alliance.

As will be seen, the courts' approaches in these three groupings derive from their perceptions of certain realities of public discourse. The truth-seeking value appears to go hand-in-hand with practical, on-the-ground assessments of how citizens actually engage with each other in public discussion-especially assessments of what contributes to, or undermines, the vitality of that process. Seeking truth from the process requires truthfulness about what the process is, and battles over the realities of the process are necessarily intense.

\section{A. Truth of the Past}

Often the search for truth involves examining the past for origins or early signs of current social problems. "How did we arrive at the present difficulty or crisis?" is a question that speakers ask about issues and then make great efforts to answer by looking at past events. The question becomes urgent when a current problem is especially baffling and seems beyond solution. When a speaker probes the past for answers, finds a set of circumstances that appears both relevant and emblematic of the issue in its earlier stages, and then communicates a theory based on that 
research, legal questions can arise if the speaker's account of past facts negatively portrays another person. That person may complain of being reduced to a symbol or a stereotype. The charge may be that the speaker has neglected the allegedly emblematic figure's complexity as a person, or that the speaker has subordinated the figure to the status of victim of whatever social forces are being described. Challenging questions then arise about the truthfulness of the speaker's presentation of the figure and of the past events in which he played a part. The figure may denounce the speaker for ignoring his moral agency, while the speaker may insist that discussion of current problems inevitably involves creative, even selective, use of the past to generate solutions and inspire action. Ultimately these disputes ask whether individual stories can truthfully be "representative" of the past.

The law thinks they can, taking an optimistic view of the retrievability and uses of past truth. Two examples of the law's optimism are Haynes v. Alfred Knopf and Sidis v. F-R Publishing Co. ${ }^{209}$ In each, an author addressed a troubling issue by using a named individual and his experience to humanize the issue and give it immediacy. In Haynes, journalist Nicholas Lemann explored the twentieth-century migration of black families from the rural South to northern cities, focusing on the profound pressures caused by dislocation. One part of his study told the story of an African American couple, Luther and Ruby Haynes, and the effects of migration on them and their children. Ruby was Lemann's source for many details about Luther's drinking, infidelity, and corrosive conflicts with family members. Stung by the book's unflattering account of his character, Luther Haynes sued Lemann and the book's publisher for invasion of privacy, arguing that the defendants' public disclosure of his private facts warranted an award of damages. ${ }^{210}$ In Sidis, author James Thurber addressed a less prominent but still important issue: the effects of a particular method of raising gifted children. Thurber examined the life of William James Sidis, a prodigy whose parents had accentuated his intellectual gifts at the expense of other traits. Sidis achieved remarkable academic success as a boy and young man, only to crash and burn as an awkward adult and retreat into obscurity. When Thurber brought Sidis back into the public eye, Sidis bitterly objected to the story's inclusion of intimate details - of his poor hygiene, messy living conditions, and various peculiarities. ${ }^{211}$ Both cases presented questions about past truth, particularly about the scope of a speaker's license to characterize the past by drawing on personal stories and generalizing about their significance.

As plaintiffs, both Haynes and Sidis were required to prove multiple elements defined in the Restatement (Second) of Torts: that the speaker publicized their private facts, that the exposure was not simply hurtful to them but would be highly offensive to a reasonable person, and that the facts disclosed had no bearing on any

209. Haynes v. Alfred A. Knopf, 8 F.3d 1222 (7th Cir. 1993). Sidis v. F-R Pub. Corp., 113 F.2d 806 (2d Cir. 1940), cert. denied, 311 U.S. 711 (1940).

210. Haynes, 8 F.3d at 1229-30.

211. Sidis, 113 F.2d at 807 . 
"legitimate concern" of the public. ${ }^{212}$ In cases of this kind, the challenge for plaintiffs is often two-fold: to establish that the challenged facts were indeed private in the sense of not widely known, and that those facts had no reasonable nexus to a broader issue. On both points, the Haynes court treated the case as an easy win for the defendants. Writing for a federal appellate panel, Judge Richard Posner emphasized that the facts disclosed about Luther Haynes were not "intimate physical details" and thus not "private" in the requisite sense, and that the book's overarching topic - the "great black migration"- had "transcendent" public interest. ${ }^{213}$ On the latter point, Judge Posner found that the account of Luther Haynes's behavior was clearly connected to the book's main theme: that the ordeal experienced by migrant African Americans stemmed from the collision of misguided government policies with "a sharecropper morality" characterized by a certain family structure - "matriarchal and elastic"-and an "extremely unstable marriage bond." 14 Judge Posner had no problem describing Luther Haynes as a "representative figure" of this personal profile. Although Judge Posner said that a composite portrait of migrating blacks would be "racial stereotyping," the approach used in the book-providing a case history of one person as a "representative figure" - presented for the court no such problem. ${ }^{215}$

The court in Haynes granted the defendants' motion for summary judgment, noting that the "public need[ed]" the book's information about Haynes. ${ }^{216}$ But even if the case's outcome was correct, its treatment of Luther Haynes and indeed its conception of history were surely problematic. At the very least, the court was too quick to accept the assertion that Luther Haynes "represented" black experience in the sense of embodying the "sharecropper morality" and falling prey to governmental policies that exacerbated that morality's effects. Even if the book did avoid racial stereotyping, did it not come close to the same thing in casting Haynes as illustrative of a thesis about black experience? It is not hard to imagine Haynes arguing that the book had denied his own moral agency, stereotyping him as "a passive victim of impersonal forces." 217 Moreover, Lemann's approach—using individuals as historical types - carried the risk of simplifying history. Is the past adequately captured by the presentation of a "representative" man? The court's failure to acknowledge these arguments perhaps signaled a sense that, even if they had merit, no practical alternative to Lemann's use of the past was available. The court may have seen the use of Haynes's private facts as an inescapable cost of addressing current issues by searching for insights, however limited or partial, in past lives. From what other sources could solutions come?

Whereas there was no question in Haynes that the book addressed an

212. Restatement (Second) of Torts $\S 652 \mathrm{D}$ (1965).

213. Haynes, 8 F.3d at 1230, 1233.

214. Id. at 1232 .

215. Id. at $1232-33$.

216. Id. at 1233 .

217. Steven A. Reich, The Great Migration and the Literary Imagination, J. HIST. SOC'Y 87, 116 (2000). 
overarching theme of public importance, the Sidis court examined whether any such issue was involved in the first place. Unlike Lemann's book, Thurber's article about the prodigy did not explicitly claim any larger purpose than to tell a "where are they now" story. ${ }^{218}$ Seeing no high-minded theme, the prodigy-plaintiff argued that the article's "vicious" cataloguing of "sordid and purely personal items" had been written in a "sly and sarcastic" tone that pointed to "selfish commercial interests" as its sole motivation. ${ }^{219}$ At oral argument, the magazine's attorney insisted that the article had an implicit theme of legitimate public interest- that Sidis's eccentric life was a "tragic illustration of the havoc caused by the ruthless parental exploitation of gifted children."220 Thurber himself reinforced this point in a later memoir, writing that his purpose had been to "help curb the great American thrusting of talented children into the glare of fame or notoriety, a procedure in so many cases disastrous to the later career and happiness of the exploited youngsters." ${ }^{221}$ In effect, Thurber made the same type of claim that Lemann made in Haynes: that an individual's life could be seen as "representative" of an important issue and, as a result, should be protected from liability.

Writing for a federal appellate panel, Judge Charles Clarke accepted that the article dealt with a matter of public concern, but did not frame the matter in the same way as Thurber and his attorney. ${ }^{222}$ Perhaps less certain than Judge Posner that a "case history" could be readily labeled as "representative" of past historical circumstances, Judge Clarke may have seen that ratifying Thurber's characterization of the larger issue would have required the court to address whether Sidis's life was in fact an illustration of the issue. Could it be said with any degree of certainty that Sidis's adult behavior was solely — or even largely — a product of being "thrust into the glare of fame and notoriety" as a child by misguided parents? Judge Clarke and his fellow judges may have doubted their ability to answer that question. They may also have doubted the underlying notion that the trajectory of an individual's life can be reduced to one major cause. Sidis himself was adamant that The New Yorker profile-far from "essaying information" - had not told his whole story, but had emphasized only the facts that supported a mocking portrait. ${ }^{223}$

Perhaps resistant to viewing Sidis as a symbol, yet recognizing the value of articles such as Thurber's, the panel chose a more modest characterization of the matter of public concern: whether the prodigy had "fulfilled his early promise."224 Stating the overarching issue this way allowed the panel to focus on Sidis as a person, rather than an emblem of lifelong victimization caused by a misdirected

218. Sidis, 113 F.2d at 807 (The profile, published in 1937, was entitled "Where Are They Now? April Fool!').

219. Brief for Appellant at 5-6, Sidis v. F-R Pub. Corp., 113 F.2d 806 (2d Cir. 1940).

220. Samantha Barbas, The Sidis Case and the Origins of Modern Privacy Law, 36 ColuM. J. L. \& ARTS 21, 41 (2012).

221. JAMES THURBER, THE YEAR WITH ROSS 186 (1959).

222. Sidis, 113 F.2d at 809.

223. Brief for Appellant, supra note 219, at 5-7.

224. Sidis, 113 F.2d at 809 . 
childhood. The court steered clear of any suggestion that Sidis was "representative" of anything but his own life. With a more modest statement of the article's concern, it was not difficult for the court to trace a linkage between that issue and the article, and to regard the article's implicit answer- that no, Sidis had not fulfilled his promise - as either a protected opinion or a factual statement unlikely to be contested. Much more than the opinion in Haynes, the Sidis opinion seemed aware of the risk of public issue writing: that it often depends on illustrations provided by the lives of real people but that the illustrations, properly understood, should not purport to capture the whole truth of a human life.

Unfortunately, the analysis in Sidis was curt, and the court's reasons for reframing the larger issue were not spelled out. This leaves us with only hints about its approach to past truth and its uses. What can be gained from facts of the past besides the facts themselves? Can historical individual stories plausibly tell larger truths? The fact that the courts in Haynes and Sidis take such different roads to the same conclusion - that the lawsuit must fail — suggests the need for further reflection about the availability of past facts to establish something meaningful about current conditions.

This question is at the heart of a Booker Prize-winning novel, Staying On, by British author Paul Scott. ${ }^{225}$ The novel was published towards the end of Scott's life, a coda to his more famous work, The Raj Quartet (a sequence of novels set in India in the last years before Indian independence). ${ }^{226}$ The Raj Quartet is considered "among the greatest prose fictions" of modernist literature. ${ }^{227}$ In these novels, Scott recounts the interlocking stories of various British and Indian characters in the waning days of British colonial rule. His theme is that the moral "promise" of friendship and respect originally made by England to India had not been kept, and that commercial and political self-interest, fueled by racism, had led to incalculable human damage. ${ }^{228}$ As the Quartet draws to an end in the independence celebrations of 1947, most of the English characters book passage for uncertain futures in England. Two minor characters, Tusker and Lucy Smalley, plan to remain in India, and in Staying On, the Smalleys assume center stage. A compelling blend of comedy and pathos, the novel depicts their situation twentyfive years after independence, their compatriots and the trappings of privileged life long ago dispatched. Now in their old age, the Smalleys rely heavily on Indian employees for daily needs as their Indian landlady schemes with a corporate developer to sell the childless couple's lodgings and turn them out. Lucy, lonely and isolated, is convinced that their lives have been wasted, while Tusker masks his similar intuitions in gruff talk and occasional heavy drinking. ${ }^{229}$

225. PAUl SCOTt, StAYing ON (Avon ed. 1979).

226. In order of publication, the four novels are: THE JEWEL IN THE CROWN (1966); THE DAY OF THE SCORPION (1968); THE TOWERS OF SILENCE (1971); and A Division OF THE SPOILS (1975).

227. Eva Brann, Tapestry with Images: Paul Scott's Raj Novels, 23 PHIL. \& LiT. 181, 187 (1999).

228. For a perceptive analysis of Scott's themes, see FrANCINE S. WEINBAUM, PAUL SCOTT: A CRITICAL STUDY (1992).

229. The Smalleys were "the last surviving members in [the city of] Pankot ... of the old school of 
The novel's central concern, revealed gradually by Scott, is the fragility of truth, thought of in at least two different ways. The first concerns the human need to disguise the truth. Scott pursues this theme in largely comic fashion. The Smalleys realize that their financially ruthless landlady has quietly changed a term of their lease without making the change clear to them: the revised agreement omits the landlady's long-time duty to tend the Smalleys's small yard and maintain their garden. ${ }^{230}$ Besides invoking the biblical image of a lost garden, Scott artfully shows in miniature how English and Indian roles have changed in post-Raj India: whereas the former relationship between the two countries involved a moral promise - that English colonial rulers gave lip service to but completely failed to honor-the "new" relationship is governed by coldly legal arrangements like the lease. Contract law replaces moral responsibilities, and linguistic cleverness gives the upper hand to now powerful Indians. Aware that the change in terms will enrage Tusker, and perhaps make him ill, Lucy plans an elaborate "deception."231 Without telling Tusker, she hires a boy to care for the grass and garden and makes the arrangement appear as if the landlady provides it. Lucy's goal is to spare Tusker the humiliation of finding himself openly exploited. Scott's little story works on several levels. First, it conveys how deception is needed to make life bearable for the British who have stayed on, even twenty-five years after the collapse of the Raj. Scott's point here is similar to the point of George Orwell's famous essay, Shooting the Elephant. In the essay, Orwell describes how dishonesty seeped into all dimensions of life when the British were still in charge of India. ${ }^{232}$ It seems, then, that the Smalleys "illustrate" British mendacity, at least in an ironic sense. Lucy's deceptions echo the Raj's own methods of coping through deceit. On a second level, both Scott and Orwell suggest that the deception permeating colonial and post-colonial rule is a metaphor for the deception that permeates human relations generally, poisoning relationships at the same time that it makes them possible. The Smalleys seem to "illustrate" this point as well.

Scott is more interested in a second theme related to truth. The Smalleys are aware that they are occasionally presented to tourists who ask whether there are "any old-style British around here." ${ }^{233}$ The Smalleys themselves have joked about being placed on "the tourist itinerary" as a "tableau vivant" of remnants of the Raj. ${ }^{234}$ That prospect seems less amusing when Lucy Smalley learns that a young historian from Cambridge will be arriving in India. The historian, Mr. Turner, hopes to meet the couple, hear about their post-Raj experiences, and possibly write about them. Lucy worries that, although Turner could turn out to be "a sympathetic

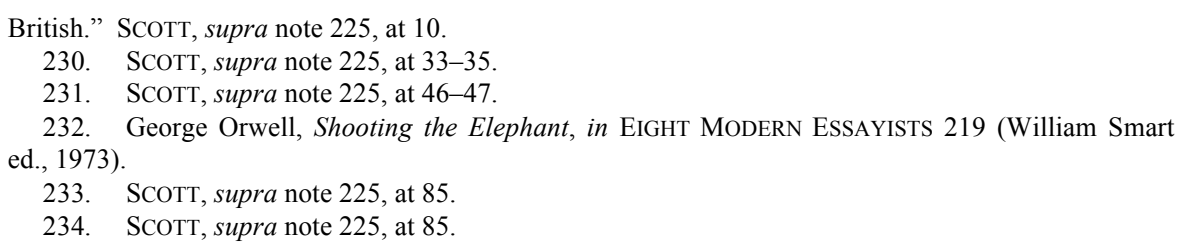


listener," he might just as likely "laugh[] at us like a drain."235 Worse, even if Turner merely "want[s] to know what it has been like" for the Smalleys to live in India after independence, Lucy knows that "it has not been like anything because it has been different for everybody, just as it has been different for me and different again for Tusker."236 Lucy's concerns are thus two-fold: first, that treating a person as representative of a public matter reduces the person's complexity and, ultimately, his humanity - as Thurber arguably did in making Sidis a stand-in for gifted children thrust into notoriety by their parents; and second, that claiming that one person's experience can illustrate the experience of others is simply false, because people with diverse origins, temperaments, and past experience encounter the same conditions in vastly different ways. In this respect, the truth of a person's moral experience is both impossible to know and meaningless to use to characterize a larger group.

Despite all this, Lucy has a sense of inevitability that, no matter what, the historian will judge the Smalleys and attribute some kind of symbolic significance to them. As she awaits his arrival, she begins a series of mental conversations with him, in effect seeking a fair hearing and offering her testimony. ${ }^{237}$ In her mind, Lucy defends and grapples with the Smalleys's history. These recollections suggest that she could never be a mere symbol. Far from being representative of the prejudices and delusions of the Raj, Lucy is revealed to have detested British class-consciousness and longed to relocate to a part of India that was remote from the main action of the Raj. ${ }^{238}$ Her recollections of Tusker's failure to advance in his military career and the resulting impact on their social position invariably end not in answers but questions that become increasingly clear-eyed about her own aspirations and failings.

Lucy then poses some of these questions to Tusker, realizing that he may die soon. Tusker is thereby forced into recollections of his own. It turns out that he too was far from a partisan of the Raj. A functionary who, unknown to Lucy, chafed at the absurdities of the military class, Tusker had deliberately avoided opportunities to advance. His memories are telling: "[I] invested in India, not money which I've never had, not talent (Ha!) which I've only had a limited amount of, nothing India needed or needs or has been one jot the better for, but was all I had to invest in anything. Me."239 These reflections lead to an effort by Tusker to communicate on a more loving, personal level with Lucy. But he cannot answer everything she has asked, and his death leaves her with further questions. The novel wholly dissuades the reader from seeing Lucy and Tusker as illustrations of issues or groups. Rather, each is a solitary consciousness. ${ }^{240}$ Saddled with layered backgrounds, the Smalleys struggle towards a sense of purpose within an

235. SCOTT, supra note 225, at 105.

236. SCOTT, supra note 225 , at 157.

237. SCOTT, supra note 225, at 145-59.

238. SCOTT, supra note 225, at 156.

239. SCOTT, supra note 225, at 83, 212-14.

240. SCOTT, supra note 225, at 156. 
oppressive milieu. They connect with each other and those around them only fitfully, yet they manage in the end to see themselves honestly through the odd clarity of questions.

Scott thus challenges the confidence of a decision like Haynes, where the court suggested that an author can readily summarize an era or social group by excavating the story of one person or one couple. For Scott, truth telling is a different activity altogether, a chronicle of lives for their own significance. As Staying On ends, Lucy is widowed, grieving, and afraid of isolation, but she resolves to keep her appointment with the historian. ${ }^{241}$ She understands that Mr. Turner will never be able to tell the couple's full story or to resist remaking them as symbols, but she bargains that something accurate and useful might indeed be salvaged: not a depiction of the Smalleys as "representative," but an account of two individuals whose own idiosyncratic lives revealed them as part of-yet at the same time not part of - the foreign ruling class in India. Even this account would be incomplete, but it would be an example of "practical realism." As historian Gordon Wood has written, practical realism "recognizes that there cannot be an exact correspondence between words and what is out there," yet "continues to aim for as much accuracy and completeness as possible in the historical reconstruction of the past. Our interpretations of the past may be imperfect, but practical realism knows that some words and conventions, however socially constructed, reach out to a world and give a reasonably true description of its contents."242

To take the modest approach of the Sidis court and say that the partial account accurately provides one aspect of the British experience in India - that some small number of the British were more comfortable with Indian society than with their own, and therefore remained after independence-would be consistent with Wood's understanding of "practical realism." As for Scott, it is likely that he regarded the Smalleys as "representative" only in an ironic sense: they reflected not historical types but humanity itself. Their experience of love, isolation, and bafflement is central to his story, and Lucy's last thoughts are framed as questions, probing the nature of human longing. ${ }^{243}$

\section{B. Truth of the Present}

The previous section discussed complications from using lives as illustrations to salvage truth of the past. We turn now to a set of cases involving present truth. Here, speakers addressing public issues do not use illustrative speech; instead, their method is to publicize the words of another person, office, or entity in order to expose some untoward aspect of power or privilege. In these cases, parties on the

241. SCOTT, supra note 225, at 234-35.

242. Gordon S. WoOd, The Purpose of the Past: Reflections on the USES OF History 141 (2008).

243. Scott's biographer notes that "at the heart of the book is Lucy's plaintive cry . . . lamenting loneliness, deprivation and neglect." Hilary SpURling, PaUl SCOTT: A LifE OF THE AUTHOR OF THE RAJ QUARTET 382 (1990). 
verge of exposure, or who have been exposed and seek to discourage further attention, use the legal system in an effort to silence the speaker. Sometimes they seek injunctions, sometimes they seek the closure of a courtroom or another site of decision-making, and sometimes they use legal devices with obvious intimidating effect. As discussed in this section, courts have developed strong legal doctrine in order to discourage these silencing attempts. In many instances, the doctrine is sufficient to allow speakers to impeach the powerful through their own words. The assumption is that application of this potent anti-silencing doctrine will yield immediate benefits. Yet courts rarely pause to reflect on what those benefits are and what else may be needed for them to materialize. Moreover, courts too seldom link the doctrine to truth-seeking and thus miss an opportunity to inquire further about the underlying goals of the First Amendment.

Prior Restraint. The clearest cases involving "present truth" involve prior restraint. While prior restraint doctrine does not differentiate between true and false speech - it protects both from advance suppression - certain social players try to use the law's tolerance for prior restraint in exceptional situations as a tactic to suppress truthful speech. ${ }^{244}$ Thus, in a number of well known cases of prior restraint, the purpose of the party seeking the restraint was to silence truthful reporting. Moreover, the content of that truthful reporting was the party's own words.

For example, in New York Times Co. v. United States, the Times sought to publish classified government speech. ${ }^{245}$ The documents included excerpts from a previously unreported archive of the Defense Department on the American buildup in Vietnam from the late 1940s through the end of the 1960s ("the Papers"). ${ }^{246}$ In the earliest stages of planning the archive, Defense Secretary McNamara had focused on truth-telling: fearful that primary documents would be lost, he wanted to preserve a record for posterity and create an "encyclopedic and objective" account of how U.S. war efforts began, gradually escalated, faltered, and were almost certain to fail. ${ }^{247}$ The material that the government sought to suppress was thus true in the sense of being the actual content of the archive, and it was "present" in the sense that the war was ongoing, hundreds of thousands of troops were achieving inconclusive results, and domestic dissent was widespread. In their watchdog roles, the New York Times, the Washington Post, and other newspapers wanted to bring this archive to public attention in large part because its contents were, in many instances, completely at odds with contemporaneous official claims, confirming suspicions that the government had lied before and was probably still lying about prospects for success. ${ }^{248}$ As Floyd Abrams has written, "The documents were devastating, demonstrating an extraordinary level of governmental duplicity, based on an unprecedented source - the very files of the Government

244. See generally DANIEL A. FARBER, THE FIRST AMENDMENT 50-53 (4th ed. 2014).

245. N.Y. Times v. United States, 403 U.S. 713 (1971) (per curiam).

246. See generally SANFORD J. UNGAR, THE PAPERS AND THE PAPERS 13, 25-28 (1972).

247. FloYd ABRAMS, SPEAKING FREELY: TRIALS OF THE FirST AMENDMENT 8 (2005).

248. KOVACH \& ROSENSTIEL, supra note 4, at 47-49. 
itself."249 The Post, for example, was able to show that, although McNamara had told the press at a particular news conference in 1963 that he and President Johnson had just reviewed war operations and were confident of success, the documents showed that McNamara in fact had given the President a very pessimistic appraisal that very day. "What might have happened," asked a Post editor after the Papers were published, "had the truth emerged in 1963 instead of 1971" about McNamara's real misgivings and about what he had said to the President? ${ }^{250}$

Tormented about the war's hopeless direction, McNamara ordered assemblage of the archive in 1967, saying, "Let the chips fall where they may." acknowledged that at some undetermined time, the documents' truth would become public knowledge. Yet, with little certainty about what, if any, danger their publication would cause, the U.S. audaciously sought to silence the Times-and thus keep the government's own thinking hidden — by obtaining a restraining order against publication. The litigation consisted of an astonishing two-week marathon from Foley Square to the Supreme Court over questions about what the Pentagon Papers revealed and about whether their publication would lead to the deaths of soldiers or the breakdown of peace talks. The government could establish neither. ${ }^{252}$ When the smoke cleared and the Supreme Court struck down the injunctions, a commentator said that the saga "signaled the passing of a period when newspapers could be expected to play by tacit rules in treating matters that Government leaders deem confidential.," ${ }^{253}$ The truth-seeking process was shown to have hitherto unexplored dimensions: it was one thing for a newspaper to report what a source had revealed about government behavior, but another thing for a newspaper to unveil official misrepresentation - especially about the prosecution of a war-by exposing the government's own hidden speech.

Private entities have attempted a similar kind of silencing. In 1997, a corporate defendant in a federal lawsuit sought to suppress reporting based on sealed documents in the lawsuit. ${ }^{254}$ Procter \& Gamble had sued Bankers Trust, alleging fraud in selling derivatives, which one judge in the case called "a particularly newsworthy investment these days." ${ }^{, 255}$ P\&G claimed losses in excess of $\$ 100$ million. ${ }^{256}$ The parties agreed to a protective order allowing them remarkably free rein to seal documents from public inspection. ${ }^{257}$ When BusinessWeek obtained the latest round of documents without violating any law or order, including a 300-page amended complaint, the magazine prepared a story about the contents of the new

249. FlOYd ABRAMS, FRIEND OF THE COURT: ON THE FRONT LINES WITH THE FIRST AMENDMENT 138 (2013).

250. Kovach \& Rosenstiel, supra note 4, at 48-49 (quoting Ben Bradlee).

251. UNGAR, supra note 246, at 28.

252. ABRAMS, supra note 247, at 44-49 (discussing per curiam order of the Court and the separate opinions of the Justices).

253. ABRAMS, supra note 249, at 143.

254. Procter and Gamble Co. v. Bankers Trust Co., 78 F.3d 219 (6th Cir. 1996).

255. Id. at 229 (Brown, J. dissenting).

256. Id. at 222 .

257. Id. 
filings. It was thought that the allegations would spark considerable interest among other companies and shareholders. ${ }^{258}$ However, $P \& G$ and Bankers Trust demanded that the protective order take priority and persuaded a federal judge to fax a restraining order to the magazine, completely without benefit of First Amendment argument. ${ }^{259}$ The judge later defended his action by likening BusinessWeek's lawful receipt of the litigation materials to "absconding with sealed documents from a courthouse." 260 In the end, a federal appellate panel held that "the private litigants' interest in protecting their vanity or their commercial self-interest simply does not qualify as grounds for imposing a prior restraint.,"261

Closure and Sealing Orders. Because prior restraint is rarely successful, powerful entities have tried other methods of blocking truthful coverage of current governmental actions. A compelling recent example comes from Delaware. In 2009 , state legislators enacted "private arbitration" legislation in an effort to remain "a magnet for corporate litigation."262 Pursuant to the statute, Delaware Chancery Court judges, already noted for their expertise and adjudicative efficiency, were authorized to arbitrate certain business disputes in courtrooms that would be closed to the press and public. Calling the plan an "interesting experiment," one commentator suggested that confidentiality was a key attraction of the plan: "[A lot] of people do business together and may not want their dirty linen in public, so to speak."263 The plan's rules were clear: eligible disputes would be those involving at least $\$ 1$ million; litigants would agree to pay $\$ 12,000$ in filing fees and $\$ 6000$ per day of arbitration; at least one party would be a business entity formed or organized in Delaware; and neither party would be a consumer. ${ }^{264}$ Press coverage of the handful of arbitrations that took place after the statute passed pointedly mentioned that the ban on attendees included shareholders. ${ }^{265}$

A citizens' group challenged the statute in Delaware Coalition for Open Government v. Strine, arguing that the press and public had a qualified First Amendment right of access to state-sponsored arbitrations. ${ }^{266}$ Obvious questions

258. BuSINESSWEEK, The Story You Should Be Reading, Oct. 1, 1995 (editorializing that judicial order was unconstitutional and withheld information from "dozens of companies and millions of shareholders").

259. Proctor and Gamble Co., 78 F.3d at 222.

260. Judge John Feikens, Guarding Privacy Rights of Litigants Against Nonparties, 15 CoMM. LAWYER 1,1 (Spring 1997).

261. Proctor and Gamble Co., 78 F.3d at 225.

262. Judith Resnik, Renting Judges for Secret Rulings, Opinion Pages, N.Y. Times (Feb. 28, 2014), http://www.nytimes.com/2014/03/01/opinion/renting-judges-for-secret-rulings.html.

263. Steven Davidoff Solomon, The Life and Death of Delaware's Arbitration Experiment, N.Y. TimeS (Aug. 31， 2012), http://dealbook.nytimes.com/2012/08/31/the-life-and-death-of-delawaresarbitration-experiment/.

264. Delaware Coal. for Open Gov’t, Inc. v. Strine, 733 F.3d 510, 512 (3d Cir. 2013), cert. denied, 134 S. Ct. 1551 (2014).

265. Peg Brickley, Secrecy Puts Judges on Defense in Delaware, Wall St. J. (Feb. 21, 2012), (noting that the statute "shut[s] the public and investors out of high-stakes corporate litigation"), http:// www.wsj.com/articles/SB10001424052970204131004577235240702540000.

266. Delaware Coal., 733 F.3d at 515. 
affecting the public had been removed from the public eye: the nature of corporate conduct at issue in a given proceeding, implications for investors, the rulings and outcomes reached by Chancery judges, and the likely significance. A federal district court ruled that the statute violated the First Amendment, and a split panel of the U.S. Court of Appeals for the Third Circuit affirmed. ${ }^{267}$ Unfortunately, this challenge produced multiple judicial views about the applicable First Amendment framework and rationale. The lack of clear guidelines may embolden other efforts to close courtrooms in contexts not identical to this one.

Besides closing courtrooms, courts have used sealing orders that have the effect of restricting truthful reporting. In a recent civil case brought by a corporation against the Consumer Product Safety Commission, the plaintiff, a manufacturer, convinced a federal judge to conduct much of the litigation "behind closed doors." ${ }^{268}$ The plaintiff sought to block the agency from posting on its public database a consumer's report that the plaintiff's product had injured a child. Because the statute authorized manufacturers to object to postings containing inaccurate or confidential information, the plaintiff had opposed the posting and sued when all of its objections were not met. ${ }^{269}$ The plaintiff insisted that possible harm to its reputation justified its litigating under seal and proceeding under a pseudonym. Despite the protests of a citizens group, the trial judge agreed, labeling as "abstract" the interest in public access to litigation and ordering permanent sealing of numerous documents. ${ }^{270} \mathrm{~A}$ federal appellate panel later reversed, although a concurrence cast at least some doubt on the vigor of the First Amendment ruling. ${ }^{271}$

Intimidation. Another silencing tactic is sheer intimidation, whether carried out by government or a private entity. Again, the cases feature attempts to silence those who seek to publicize the words and conduct of a government unit or private entity. In Bridges v. Gilbert, a state inmate, Bridges, provided an affidavit and agreed to testify in a wrongful death suit about what he heard prison employees say in an adjacent prison cell on the night a fellow prisoner died. ${ }^{272}$ After providing the affidavit, Bridges began to believe that prison employees were retaliating against him for his testimony. In the inmate's own suit against the prison and various employees, the issue was whether Bridges's testimony qualified for First

267. The district court found that because Delaware's government-sponsored arbitration was "sufficiently like a trial," and because a right of public access applies to public trials, a right of public access must also apply to Delaware arbitrations. Delaware Coal. for Open Gov't v. Strine, 894 F. Supp. 2d 493, 500 (D. Del. 2012), aff'd, 733 F.3d 510 (3d Cir. 2013) (citing El Vocero de P.R. v. Puerto Rico, 508 U.S. 147, 149-50 (1993)). The appellate court applied the "experience and logic" test and found a "First Amendment right of access" to the state-sponsored arbitrations. Delaware Coal., 733 F.3d at 521.

268. Doe v. Public Citizen, 749 F.3d 246, 252 (4th Cir. 2014).

269. Id. at 254.

270. Id. at 255 (recounting lower court's rulings).

271. Id. (Hamilton, J., concurring in judgment) (stating that district court's sole error was misunderstanding "quantum of evidence" required for sealing "bulk of the court record").

272. Bridges v. Gilbert, 557 F.3d 541, 544 (7th Cir. 2009). 
Amendment protection. ${ }^{273}$ To answer the question, a federal appellate panel examined whether the First Amendment required that the speech be of "public concern" or whether the speech need only be "reasonably related to legitimate penological interests." 274 The panel chose the latter test, ruling that "truthful speech that describes possible abuses" is "consistent with legitimate penological objectives" and thus receives constitutional protection. ${ }^{275}$ By adopting this test instead of the more demanding "public interest" standard, the panel in effect invoked the truth-seeking value of the First Amendment in a context where speakers are "shut off from the outside world" and have few if any options to hold government power accountable. ${ }^{276}$ In this case, one of those options was the right to unveil present truth in the sense of repeating the very words of power.

Non-governmental entities have other means to intimidate speakers seeking to expose the entities' language and behavior. A device that has been linked to potential intimidation is pre-service discovery to identify a John Doe critic on the Internet. In Dendrite International v. Doe, No.3, a corporate plaintiff sought to learn the identity of an anonymous critic who had posted quotations from the corporation's earnings report, along with disparaging comments, on a website's message board. ${ }^{277}$ The publicly traded company, Dendrite International, decided to sue the anonymous blogger and moved a state court for an order directing the website to identify the blogger. ${ }^{278}$ On these facts, the court saw its task as developing a framework that would sensitively balance the John Doe critic's qualified First Amendment right to speak anonymously and the corporation's interest in suing to vindicate its reputation. ${ }^{279}$ The goal, said the court, was a framework that would prevent use of pre-service discovery "to harass or intimidate" speakers. ${ }^{280}$ It noted that Internet users "should be able to participate online without fear that someone who wishes to harass or embarrass them can file a frivolous lawsuit and thereby gain the power of the court's order to discover their identity." 281 On this reasoning, the court rejected the more lenient test for unmasking John Doe. Because the threat of unmasking could chill "John Doe" bloggers in the first place, the court chose a multi-prong test that was designed to err on the side of protecting speech.

The point is not that all silencing efforts should be forbidden by the First Amendment on the ground of truth. The truth-seeking value has never claimed that First Amendment protection must be absolute. Rather, the point is that, even today, powerful entities seek on occasion to block truthful communication, and that an

273. Id. at 545 .

274. Id. at $547-48$.

275. Id. at 551 .

276. Id. at 550 .

277. Dendrite Int'l, Inc. v. Doe, No. 3, 775 A.2d 756, $762-63$ (N.J. App. Div. 2001)

278. Id. at $763-64$.

279. Id. at 771

280. Id. at 767,771

281. Id. at 767 (quoting Columbia Ins. Co. v. Seascandy.Com, 185 F.R.D. 573, 578 (N.D. Cal. 1999)). 
implicit consideration in making and applying legal doctrine has been that the content sought to be blocked is truthful information—often, hidden words of the powerful. Another implicit premise of the cases is that a process is at work: the transmission of protected information to recipients for whom it is of legitimate interest or even of vital importance. The ideal of a speech process is that recipients use the information they receive to further their conceptions of the best interests of society. On this view, the negative liberty afforded by First Amendment doctrine enables information to reach citizens, who, in discussing, reflecting upon, and otherwise following-up on the information, have the option of exercising positive liberty - the freedom to act for the good of society as they conceive it. ${ }^{282}$

But this idea of a speech process for the transmission and use of truthful information is still too abstract to capture the possible depths of the truth-seeking value and its connection to present truth. Bernard Williams offers a clue in Truth and Truthfulness. ${ }^{283}$ In a discussion of Orwell's 1984, Williams examines the depiction of relentless state torture used to force the protagonist, Winston Smith, not only to say but also to believe that two plus two equals five. Williams takes strong issue with Richard Rorty's interpretation of this scene. ${ }^{284}$ Rorty had argued that Orwells's ethical and political point had nothing to do with truth or falsity but was to criticize the state for impeding the protagonist's right to say what he believes (that two plus two equals four) ${ }^{285}$ According to Williams's quite different interpretation, Orwell's point was precisely about truth and falsity - that the ethical and political evil was both the state's prevention of speech, but more deeply, the state's destruction of "the victim's relation to the world altogether, undoing the distinctions between fantasy and reality." 286 For Williams, the state power asserted in 1984 was an assault on Winston's "sense of reality and capacity for true belief," a point that Rorty had failed to understand or acknowledge. ${ }^{287}$ The cases involving present truth are connected by a theme of power-whether used by state or private entity - to keep information out of the public's reach. Perhaps the cases do not involve acts of power as audacious or violent as that imagined by Orwell, but the strong doctrines developed by courts display a wariness of power all the same, particularly its ability to come between the individual and his "world."

Kazuo Ishiguro's novel, Never Let Me Go, deepens the latter theme. ${ }^{288}$ Telling a story of a speech process and its effects, the novel posits that the ultimate objective of the process is relational in the sense of producing a particular kind of link between the person and his or her social context. Ishiguro imagines a society like ours with one key difference: through scientific advances, human cloning has

282. For a more detailed discussion, see Brian C. Murchison, Speech and the Self-Governance Value, 14 WM. \& MARY BILL RTS. J. 1251, 1279 (2006).

283. WILLIAMS, supra note 80

284. WILLIAMS, supra note 80 , at $146-48$.

285. WILLIAMS, supra note 80 , at 147.

286. WILLIAMS, supra note 80, at 148.

287. WILLIAMS, supra note 80.

288. KAZUO Ishiguro, NeVER LET ME Go (2005). 
been made possible. The purpose of cloning is to further the health of the general population by creating a stable supply of human organs for transplantation. In tracing the lives of three clones from childhood through early adulthood, Ishiguro raises questions about the social responsibilities of creating a sub-class of human beings. ${ }^{289}$ As in his other novels, Ishiguro's intentions are "metaphorical" as well: recounting the story of his central characters allows him to reflect on questions and conditions that burden all of human life. ${ }^{290}$ Part of the metaphorical story concerns the search for truth undertaken by Kathy H., the narrator, and her friend, Tommy.

The early chapters are devoted to the mostly idyllic childhoods of the clones at Hailsham, an English boarding school located in the countryside, complete with playing fields, a duck pond, and kindly teachers. The clones have a normal education, but they grow up as orphans isolated from society. Although the school tells them that they are clones and will eventually "donate" parts of their bodies, the school delivers the information in dribs and drabs, mixed with other information to reduce its impact, and delivered when the clones are too young to fully grasp what is being said. As one of their teachers fumes, "You've been told and not told.",291 Against this backdrop of limited knowledge and incomplete understanding, the clones grow up with only a few, including Kathy H., bold enough to detect clues, ponder their meaning, ask questions, and discuss the mysteries of their lives. Hailsham closes when its mission of providing a normal education for clones falls out of political favor in England. ${ }^{292}$ Cut off from this physical connection to her secure childhood, Kathy continues in her twenties to search for an accurate understanding of her existence and fate.

As in the India of Staying On, an underlying air of deception permeates Kathy's friendships and surroundings, but she and Tommy are closely linked from the start. Out of the murkiness of their education, a rumor circulates that if two of the clones fell truly in love, they could obtain a "deferral" from the duty to donate and thus exemption from death in early adulthood. ${ }^{293}$ It becomes the mission of Kathy and Tommy to discover whether this rumor has any truth and thus whether they could somehow escape their fates. Their seeking leads them to the home of Emily, the one-time headmistress of Hailsham, who may hold the answer to many of the questions that filled their young lives, including the rumor of deferrals. Kathy's calm insistence that Emily answer questions resembles the pressings of citizen groups for access to the information withheld by governments or corporations. Like Winston Smith and like the citizen groups of First Amendment access cases,

289. ISHIGURO, supra note 288 , at 263

290. “Throughout my career," Ishiguro has stated, "I've struggled to encourage people to read my books on a more metaphorical level ... . I was always looking at how we live, how all of us live." Concerning Never Let Me Go, Ishiguro said that he was "interested in the human capacity to accept what must seem like a limited and cruel fate." SPIEGEL Interview with Kazuo Ishiguro, SPIEGEL ONLINE INT'L (Oct. 5, 2005, 5:31 PM), http://www.spiegel.de/international/spiegel-interview-with-kazuoishiguro-i-remain-fascinated-by-memory-a-378173.html [http://perma.cc/CBK3-MB4J/].

291. ISHIGURO, supra note 288 , at 81 .

292. ISHIGURO, supra note 288, at 263-65.

293. ISHIGURO, supra note 288 , at 252. 
Kathy's quest for truth is part of a larger quest for freedom: are the clones truly subject to the demands of the donation program, or do they have another option? Kathy and Tommy doggedly pursue any possibility of reprieve.

Emily, whose liberal values informed her leadership of Hailsham, answers Kathy's questions, but her values turn out to be surprisingly shallow. Although Emily sympathizes with her former students - even more so now in a political environment that has lost its former compassion for clones-she maintains her reserve. ${ }^{294}$ In the scene in which she agrees to meet with Kathy and Tommy, she simultaneously supervises the removal of valuable furniture from her home. Juxtaposing furniture and clones, Ishiguro suggests that even an ally sees Kathy and Tommy as objects - valuable, but not quite human. Nevertheless, Emily respects them enough to answer their questions: deferrals are not available; and the rumor - that love can earn them an exemption-is baseless. Of course, the literalistic Emily never sees Ishiguro's larger irony-that the rumor $i s$ true: the loving relationship between Kathy and Tommy has enabled them to cheat, at least in a figurative sense and if only temporarily, the fate that society's indifference has assigned them.

But the novel does not end with the release of sought-after facts from a former teacher. Like Bernard Williams, Ishiguro is interested in the effects of a speech dynamic. What happens next-after the petitioning and forcing of power to provide crucial information? What is the effect of receiving information that a speech process at least sometimes makes available? In the last twenty pages of the novel, Ishiguro shows that, with their futures grimly clarified and the illusion of deferrals erased, Kathy and Tommy enter into different relationships with themselves, each other, and the world they inhabit. The information first provides a basis for greater self-knowledge. For Tommy, the background history provided by Emily about Hailsham confirms the sense he had had since early childhood that the school was withholding crucial facts and that its lack of candor was wrong. ${ }^{295}$ Tommy's tantrums as a child turn out to have been prescient, and this realization seems to increase his present self-respect. For Kathy, the information obtained from Emily provides the stamina to do what she has most deeply resisted-letting go of Tommy as he prepares for his fourth "donation," which will undoubtedly be fatal. ${ }^{296}$ Following these separate experiences of growth, Kathy and Tommy find a new honesty in their relationship: it is less dependent on their nostalgia for childhood and Hailsham, and more cognizant and expressive of the mature love between them. Their conversations and silences reach a quiet depth of understanding. ${ }^{297}$ Finally, the connection of each to the world is clarified. Tommy is able to confront the prospect of his impending death with unexpected resolve, and Kathy achieves the "ordering of her thoughts" that prompted her narration in the first place. Their final conversation concerns whether or not it was better that

294. IsHIGURO, supra note 288, at 265.

295. IsHIGURO, supra note 288, at 275.

296. ISHIGURO, supra note 288, at 276-79.

297. ISHIGURO, supra note 288 , at 283. 
they finally learned the facts, unlike their Hailsham friends who had already died. On this question, Tommy considers the difference between questioners and believers. "You and me," he says to Kathy, "right from the start, even when we were little, we were always trying to find things out," whereas their friends among the clones "always wanted to believe in things." 298 For truth seekers, they conclude, it is better to know, even if the knowledge is far from what they hoped it would be.

Ishiguro's implication is that the truth-seeking dynamic has allowed these characters a relationship with each other and with the world that they would otherwise not have had. Of course, the relationship has come too late, because the truth in its particulars was deferred. Perhaps in Ishiguro's seekers we hear an echo of the editor's question after publication of the Pentagon Papers: "What might have happened, had the truth emerged in 1963 instead of 1971?"299

\section{TRuth of the Future}

So far, this Article has shown that cases involving "past truth" essentially ask, "What reality of the past can be salvaged and used to deal with a current issue?" The answer, it turns out, is: "Not much, but some." In turn, cases involving "present truth" ask, "What is actually happening right now?" and the answer seems to be, "Start with the words of those in charge." Now, for cases involving "future truth," the question is: "What is coming tomorrow, and how much untruth needs to be cleared away (and by whom) in order to see it?" The set of cases in this third category are explicitly concerned with devising legal doctrine that will promote a flow of truthful speech beyond today. As such, the cases speculate on cause and effect, positing that certain rules will be more likely than others to produce an acceptable flow of truthful expression about public matters, broadly defined. The cases in this category include common-law actions for libel and statutory actions for false speech about political issues or other subject matter that the legislature seeks to regulate. Through the libel tort and the statutory causes of action, the government itself seeks to promote truthful speech and associated goals: protection of reputation, furtherance of the integrity of the judicial process, and so forth. A striking aspect of these cases is the judiciary's insistence that the First Amendment requires a different approach to promoting truth and the other goals. That approach involves a high tolerance for falsity. How is this tolerance consistent with the truth-seeking value? As discussed below, rules that tolerate at least some false speech are seen as contributing to an overall flow of truthful speech. The scope of this tolerance is controversial, as the cases pit the constitutional truth-seeking value against a common-law or statutory strategy for promoting truth by regulation. This section closes out with a discussion of a third novel, Atonement, which adds to an appreciation of the complexity of truth's tangled connection to falsity.

298. ISHIGURO, supra note 288, at 284

299. KOVACH \& ROSENSTIEL, supra note 4, at 48-49. 
New York Times Co. v. Sullivan, the classic and still vital First Amendment case that recently marked its fiftieth anniversary, seems at first blush to be driven not by the truth-seeking value but by the self-governance value of the First Amendment. ${ }^{300}$ The case famously held that the common-law action for libel, with its structure of strict liability and presumed damage, was constitutionally infirm when used by a public official against a "citizen critic of government."301 Writing for the Supreme Court, Justice Brennan prefaced the analysis by citing Justice Brandeis's observation that "[t]hose who won our independence believed . . that public discussion is a public duty," and invoking the nation's commitment that "debate on public issues [be] uninhibited, robust, and wide-open." ${ }^{302}$ In addition, Justice Brennan twice quoted James Madison's statement that the "censorial power is in the people over the Government, and not the Government over the people," and he analogized the lawsuit in Sullivan to the Adams administration's use of the Sedition Act of 1798 to punish the speech of political rivals. ${ }^{303}$

However, despite the linkage of expressive freedoms to an underlying value of self-governance, Justice Brennan's reflections on the "censorial power" pointed to an even deeper concern: the need to protect at least some false speech in order to discourage self-censorship and thus promote a generous flow of truthful public discourse over the long haul. The truth-seeking value was thus arguably the core of Justice Brennan's concern. His opinion for the Court addressed this concern by looking ahead, imagining the needs and benefits of the free-speech tradition in an ever complicating age. Examining the reality of public discourse in this country, he accepted its awkwardly robust combination of passion and reason, and twice noted the inevitability of false statements in the heat of "free debate." 304 The obvious question, then, was whether the harshness of the existing libel tort in the context of "inevitable" falsity would deter citizen-critics from speaking out on public matters in the first place. The answer was clearly "yes": if Commissioner Sullivan succeeded in wresting $\$ 500,000$ from the New York Times for publishing erroneous facts, imitative suits would jeopardize reporting of public events not only in the South but throughout the nation. ${ }^{305}$ Justice Brennan probed the likely impact of such verdicts and, again projecting forward, concluded that the main casualty would be true information. Even though truth was a defense in libel actions (and thus a defense embodying the common-law's own truth-seeking value), its constitutional adequacy was questionable at best. A potential citizen-critic could have real reason to doubt his ability to prove truth in a courtroom, even if the content of his speech were in fact true and he honestly believed it to be so. ${ }^{306}$ On

300. N.Y. Times Co. v. Sullivan, 376 U.S. 254 (1964). See also RoBert C. Post, CONSTITUTIONAl DOMAINS: DEMOCRACY, COMMUNITY, MANAGEMENT 164-67 (1995).

301. Sullivan, 376 U.S. at 282 .

302. Id. at 270 .

303. Id. at $275-76,282$.

304. Id. at $271-72$.

305. Id. at $277-78$.

306. Id. at 279 ("Under [the common law], would-be critics of official conduct may be deterred from voicing their criticism, even though it is believed to be true and even though it is in fact true, 
this reasoning, Justice Brennan showed that his primary concern in Sullivan was the tort's chilling effect on truthful information about public issues-in his words, "the pall of fear and timidity" on would-be speakers who would choose silence over the risk of liability. ${ }^{307}$ Weighing these considerations against the reputational interest of public-official plaintiffs, the Sullivan Court decided that the Constitution required the addition of two elements - falsity and fault - to a public official's prima facie case. ${ }^{308}$ The new rule would protect falsity about public officials, but its protection would not be absolute-there would be no safe haven for the calculated lie or a reckless untruth. ${ }^{309}$ The Court thus established a margin of error that it thought would facilitate a vital flow of truthful discourse, trusting that, over time, public discourse in all its diversity would lead to informed decisions by the public and its leaders.

Besides the concern for speakers as participants in public discussion and debate, Justice Brennan's opinion reflected concern for receivers of speech. How would they handle a flow of discourse that included erroneous information? To answer this, Justice Brennan recognized that the flow of speech would include the words of competing voices: speech on important matters would not likely go unchallenged. He quoted Judge Learned Hand for the point that the First Amendment "presupposes that right conclusions are more likely to be fathered out of a multitude of tongues, than through any kind of authoritative selection,"310 and Justice Brandeis for the point that "the fitting remedy for evil counsels is good ones." 311 In effect, false speech entering public discourse would likely provoke counter-speech.

A third point made by Justice Brennan was his conclusion that false speech had a not altogether undesirable function of its own. Quoting Mill's On Liberty, Justice Brennan wrote that "[e]ven a false statement may be deemed to make a valuable contribution to public debate, since it brings about 'the clearer perception and livelier impression of truth, produced by its collision with error."”312 Combining this argument with the others - that falsity was inevitable in public debate, that its protection (within limits) would help prevent self-censorship and promote truth overall, and that counter-speech could be relied upon to challenge at least some inaccuracies and misrepresentations - the Court implicitly aligned itself with Dr. King's near-contemporaneous Letter from a Birmingham Jail. ${ }^{313}$ That letter's message was clear: truth-telling about the denial of black citizens' civil rights could no longer be deferred, and the reality of conditions must be laid bare to prompt discussion, resolve, and reform.

\footnotetext{
because of doubt whether it can be proved in court or fear of the expense of having to do so.").

307. Id. at 278 .

308. Id. at $279-80$

309. Id.

310. Id. at 270 (citing United States v. Associated Press, 52 F. Supp. 362, 372 (S.D.N.Y. 1943)).

311. Id. (citing Whitney v. California, 274 U.S. 357, 375-76 (1927) (Brandeis, J., concurring)).

312. Id. at 279 n.19 (citing J.S. MILL, ON LIBERTY).

313. King, supra note 13.
} 
Some observers insist that the Court's efforts in the libel context were wrongheaded, such as Justice White, who lamented that the Court's libel jurisprudence had disserved the interest in truth. Concurring in a 1985 case, Justice White wrote, "The stream of information about public officials and public affairs is polluted and often remains polluted by false information." ${ }^{314}$ This viewpoint focused on perceived short-term negative effects of the balance struck in Sullivan and its progeny, whereas Justice Brennan's approach focused on a more distant horizon, seeing long-term positive effects of expansive freedoms, with significant protection for false speech contributing to an overall increase in the flow of truth.

This difference of emphasis - between concern for immediate "pollution" and belief in long-term flow of truth - can be seen in disputes arising from statutes that criminalize falsity in various contexts. United States v. Alvarez examined the constitutionality of the Stolen Valor Act, which criminalized knowingly false statements about the receipt of military honors. ${ }^{315}$ The targeted speech was not comparable to the "inevitable" falsities of public discourse, but consisted of specific falsities about specific subject-matter that was non-political in nature. And, recognizing that Sullivan drew the line at calculated lies and reckless disregard, Congress targeted precisely that level of culpability in the Stolen Valor Act. ${ }^{316}$ The government accordingly defended the Act as addressing non-core speech in sensitively narrow fashion. But, in a 6-3 decision, the Court protected Alvarez's false statement that he had received the Congressional Medal of Honor. Again, the Justices' ironic goal was advancing truth by protecting falsity, this time a lie.

Writing for the four-Justice plurality, Justice Kennedy noted that false speechwhen not associated with a legally cognizable harm like reputational injury or fraud - had never been considered outside the protection of the First Amendment, and that the Stolen Valor Act was best characterized as content regulation triggering strict scrutiny. ${ }^{317}$ In applying that standard of review, Justice Kennedy took the long view, making three essential points, each of them echoing Justice Brennan's analysis in Sullivan. First, the Act's scope was "sweeping" and "unprecedented": it applied to false statements made in both public and private settings, and it applied "entirely without regard to whether the lie was made for the purpose of material gain." 318 Upholding an act with such expansive reach, wrote Justice Kennedy, would have serious implications for future speech: it "would endorse government authority to compile a list of subjects about which false statements are punishable." 319 Identifying a "clear limiting principle" would be impossible, he continued, and would contradict "our constitutional tradition,"

314. Dun \& Bradstreet, Inc. v. Greenmoss Builders, Inc., 472 U.S. 749, 769 (1985) (White, J., concurring in judgment).

315. United States v. Alvarez, 132 S. Ct. 2537 (2012).

316. Id. at 2543 .

317. Id. at 2545,2548 .

318. Id. at 2547 .

319. Id. 
which "stands against the idea that we need Oceania's Ministry of Truth.",320 Justice Kennedy could foresee "an endless list of subjects" that government could "single out" for official adjudications of truth or falsity, thus consolidating "a broad censorial power unprecedented in this Court's cases or in our constitutional tradition." 321 Justice Kennedy concluded that "the mere potential for the exercise of that power casts a chill, a chill the First Amendment cannot permit if free speech, thought, and discourse are to remain a foundation of our freedom." 322

Thus, akin to Justice Brennan's recognition in Sullivan of the potentially widespread use of the libel tort against inevitable falsity in public discourse, Justice Kennedy's first step in Alvarez was to recognize the potential multiplication of statutes empowering large numbers of official truth adjudications. And then, like Justice Brennan's consideration of the chilling effect of libel actions, Justice Kennedy saw the proliferation of official truth-declaring tribunals as creating a destructive chill. Kennedy's third point, again like Justice Brennan's, was that the less restrictive solution of counter-speech rendered the Act unnecessary. ${ }^{323}$ Citing the input of citizens and public agencies in Alvarez's own situation, and the possibility of a web-based directory of actual recipients of military honors, Justice Kennedy stressed that "the dynamics of free speech, of counterspeech, of refutation, can overcome the lie." 324

The plurality opinion in Alvarez has informed judicial review of state laws criminalizing false statements in political contexts. In 281 Care Comm. v. Arneson, a panel of the U.S. Court of Appeals for the Eighth Circuit struck down provisions of the Minnesota Fair Campaign Practices Act. ${ }^{325}$ The statute targeted knowingly false statements about ballot questions when the statements appeared in paid political advertisements or campaign material. ${ }^{326}$ The statute authorized any person to bring charges of falsity against another to a state administrative office, thereby triggering a probable cause determination by administrative judges, and potentially leading to a criminal investigation and state prosecution. ${ }^{327}$ Echoing themes from the cases already discussed, the court found that the statute was prone to political

\footnotetext{
320. Id.

321. Id.

322. Id. at $2547-48$.

323. Id. at $2549-50$

324. Id. at 2549. As Justice Kennedy put it: "The remedy for speech that is false is speech that is true ... . The response to the unreasoned is the rational; to the uninformed, the enlightened; to the straight-out lie, the simple truth." Id. at 2550. On this view, the role of citizens is paramount in civic discourse: even well-intentioned governmental "suppression of speech can make exposure of falsity more difficult, not less so." Id. The objective of "open, dynamic, and rational discourse" is not advanced "when government seeks to orchestrate public discussion through content-based mandates." Id. Justice Kennedy concluded with the observation that the legitimate interest in respecting actual honorees need not be led by government: "Only a weak society needs government protection or intervention before it pursues its resolve to preserve the truth. Truth needs neither handcuffs nor a badge for its vindication." Id. at 2550-51.

325. Care Comm. v. Arneson, 766 F.3d 774 (8th Cir. 2014).

326. Id. at 778

327. Id.
} 
manipulation, that the ease with which a speaker could be subjected to state proceedings created an undeniable chilling effect, and that the "tried and true buffer and elixir" for honest elections was counter-speech. ${ }^{328}$ As the court explained, "[t]he citizenry, not the government, should be the monitor of falseness in the political arena." ${ }^{22}$ Emphasizing this capacity of citizens to sift through election speech and differentiate truth from falsity, the court relied on Justice Stevens's comment in a case invalidating state regulation of anonymous speech: "[p]eople are intelligent enough to evaluate the source of an anonymous writing. . . They can evaluate its anonymity along with its message, as long as they are permitted, as they must be, to read that message. And then, once they have done so, it is for them to decide what is responsible, what is valuable, and what is truth." 330

Of the many questions raised by these cases, one is whether the law of the First Amendment convincingly can be said to place a value on truth-seeking when it allows for a potentially great quantity of falsity. With its focus on the "long haul," is the law putting too much faith in what some surely call a "laissez faire" approach? Can citizens who justly see themselves as living in the "short term" tolerate this degree of falsity and still accept the vocabulary of truth-seeking? Does the law place too much faith in the willingness of citizens to sift and weigh, particularly when wealth disparities affect the capacity to sift and weigh in the first place? Is there too much faith in counter-speech, too much trust that competing voices will speak up or that refutation will be attempted? Is the law merely pretending to promote anything other than informational anarchy?

In a provocative essay, Eva Brann examines the connection between truth and falsity, asking whether "truth is everything and not enough," and whether falsity is in some sense "necessary to the true." 331 Perhaps Brann is merely echoing Mill, who famously argued that falsity can bring about a clearer perception, a livelier impression, of truth. Or perhaps Brann's point is different: that falsity in some instances can bring a clearer perception, not simply of truth, but of ourselves as we relate to others and society. Situating truth-seeking in the everyday lives of citizens, Brann explains her point by considering a conundrum. On the one hand, "the intellect is charged with getting things as straight as possible" and "wants not only clarity but all the ultimacy it can get to." ${ }^{332}$ On the other hand, "for life to be livable," humans often must "curtail thinking" and live "superficially," not seeking resolution of the truth-status of every question but willing to "live with compromises destructive of communal ultimates." ${ }^{333}$ She concludes that humans

328. Id. at 789-90 (noting that, in allowing anyone to lodge a complaint, the statute makes possible politically-induced diversionary tactics), 791-92 (describing "chilling nature" of the statute in terms of imposing costly burdens on those targeted by complaints), 793 (stating that "there is no reason to presume that counterspeech would not suffice to achieve the interests advanced").

329. Id. 796.

330. Id. (quoting McIntyre v. Ohio Elections Comm'n, 514 U.S. 334, 348 n.11 (1995) (citation omitted))

331. BRANN, supra note 5, at 34, 36 .

332. BRANN, supra note 5, at 12-13.

333. BRANN, supra note 5,at 8 . 
often live with a split consciousness, an "inner fracture of being," and that, confronting ideas or attitudes that appear false in some crucial respect, they often have to school themselves in the art of coexistence, discovering their own capacities for dueling virtues of tolerance and critique. ${ }^{334}$ Perhaps Brann's point is that truth-seeking for the individual includes encounters with falsity in various forms, requiring not only refinement of consciousness but developments of powers of empathy and judgment about when falsity should matter and when it need not. These encounters can lead to a complex range of self-questioning. Brann's insight that "truth is everything and not enough" in this way suggests that breathing space for falsity, even for lies in some contexts, can serve some larger positive function.

Ian McEwan's novel, Atonement, delves more deeply into the question of the complex connection between truth and falsity. ${ }^{335}$ This is a work of fiction that probes the allures and dangers of fiction seen as a form of truth-seeking. Atonement examines in particular how fiction's promise - that at least some sense can be made of reality by the ordering effects of narrative-can fall prey to destructive falsification. McEwan suggests at the same time that another kind of falsification, one inspired by empathy and a sense of quest for the reality of another person, can actually embody a form of truth, but a truth that is "everything and not enough." The levels of consciousness unveiled by this novel suggest that truthseeking indeed can and perhaps must exist side-by-side with a clear-eyed awareness of all that can be rightly labeled false.

The novel comprises three sections and a coda. Section One, the longest, is set at the English country house of the Tallis family in the summer of 1935. Family members and guests assemble for a house party, and thirteen-year-old Briony Tallis, brimming with literary imagination and the kind of personality she will later recall as "busy, priggish, [and] conceited," 336 has written a melodrama for the occasion. Her sister Cecilia is home from Cambridge; her much older brother arrives from London with a friend; cousins whose parents are bitterly divorcing are present; and Robbie Turner, the son of the Tallises's cleaning lady and the object of Briony's pre-adolescent crush, is invited to dinner. Robbie, who is also a student at Cambridge, has ambitions to be a doctor and to transcend the class barriers that stand between him and Cecilia. The scene is mostly conveyed through the eyes of Briony, whose "overanxious" imagination fuels a series of lurid misinterpretations of almost everything that takes place around her. ${ }^{337}$ In fact, the novel's opening pages recount so many misperceptions that "truth seeking" appears impossible for all concerned, particularly (but not only) for Briony. From a window, she sees and is confused by an afternoon encounter between Robbie and Cecilia. Later, she sees them in some kind of physical embrace that she again misunderstands. The clutter of contradictory emotions becomes overwhelming and prompts a need to impose imaginative order. But she disastrously stumbles upon an assault on her female

334. BRANN, supra note 5, at 58.

335. IAN MCEWAN, ATONEMENT (2001).

336. Id. at 346.

337. Id. at 116 . 
cousin on the grounds of the estate, erroneously concludes that Robbie was the attacker, and names him to the police. ${ }^{338}$ Years later, she grasps the horror of what she has done; its impact defines her life. Robbie's prison sentence ends with his enlistment in the army, in which he is caught up in the chaos at Dunkirk. ${ }^{339}$

Section One recounts the house party, the early joys and confusions of love between Robbie and Cecilia, Briony's accusation, and the arrest. Section Two focuses on Robbie's wartime experience, including Dunkirk. Section Three recounts Robbie's return to Cecilia and Briony's eventual apology to the two lovers. They do not forgive her, but there is an implication that at least some of the wrong can be righted. In the coda, the reader learns that the three Sections comprise a novel that Briony has spent fifty-nine years composing and has now completed as an elderly woman. It is revealed that, in actuality, Robbie did not survive Dunkirk, that Cecelia died in a subway explosion several months after Robbie's death, and that Briony's apology never was conveyed. ${ }^{340}$ The adult Briony's goal has been to describe the "pitiless" truth of these events in her book"to disguise nothing - the names, the places, the exact circumstances." 341 Thus, she recounts the identity of the person she had concluded was the actual rapist (her brother's guest at the house party, who later in life becomes a rich public figure and marries the girl he had raped). And, in all the drafts, written between the mid1940s and 1999, Briony has included the actual fates of Robbie and Cecilia - that they "never met again, never fulfilled their love." 342 But in the final draft, Briony, now seventy-seven years old, nearing her own death and not wishing her novel to consist of "the bleakest realism," changes key facts: the lovers survive, the apology is tendered, and the story ends on a note of hope amidst the fierce waste of war. ${ }^{343}$

The "falsity" of Briony's book, however, is entangled with truth. Section One is an imaginative delving into the inner lives of Cecilia and Robbie, their dreams, missteps, and love. Section Two similarly is a forceful attempt to convey Dunkirk - no simple narcissist could have captured it with comparable precision and agony. And Section Three, in effect, tells the story of what Briony took from Robbie and Cecilia. Briony had set in motion a chain of events that led to prison, separation, war, and death. By allowing the lovers in Section Three to elude this fate, Briony has tried to atone in the sense of acknowledging - at least to herselfthe deep consequences of the lie. ${ }^{344}$ Depicting the lovers as alive and together is, in that sense, an acknowledgment and confession of what she had denied them. For Briony, this indirect statement of truth is an achievement over her early and never

338. Id. at 169. McEwan masterfully presents Briony's mistaken thought processes as she convinces herself that Robbie was the person she had seen assaulting her cousin. "The truth was in the symmetry, which was to say, it was founded in common sense. The truth instructed her eyes." $I d$. at 159.

339. Id. at $179-250$

340. Id. at 350 .

341. Id.

342. Id.

343. Id.

344. Id. at $350-51$. 
quite vanquished self-centeredness. The reader can well understand how it took her fifty-nine years to write a book that so deeply searches out the hopes, dreams, and despair of Robbie and Cecilia. It may not be an exaggeration to conclude that Briony's lifelong reparation has been a process of getting beyond her oppressively dominating ego and arriving at an understanding of the reality and complexity of others. Her falsification allows this type of truth-telling to occur. ${ }^{345}$

Of course, Briony's change of the facts in Section Three can also be seen as a grimly self-serving alteration of reality. The lovers did not survive, and she failed to set things right. Any revision of the facts is nothing less than a misrepresentation in a work in which the other details (like the name of the rapist) are authentic. She may have set forth a life that was taken from the lovers, but she omitted the facts that it was taken and that she took it. An obvious question, then, is whether the "truth" of her falsified account, as admirable as it was for all the above reasons, was actually an unacceptable evasion of responsibility, a sign that Briony Tallis never grew beyond the myopia of her youth. By taking over the narrative in the coda, after ceding the telling to Briony for the three Sections, McEwan offers a judgment: that Briony's truth is at best partial, and that his own rendering in the final pages presents the only authentic account. Those pages capture shockingly the manipulability of truth. And in the closing lines, McEwan suggests that Briony grasps that very point: she sees that she could manipulate more, deviate even further from reality and probably find a way to justify doing so. "It's not impossible," she thinks, then adds: "But now I must sleep."346

These sentences cry out for interpretation, and at least two readings are possible. The first is that they reveal a Briony who has remained "busy, priggish, [and] conceited," ever willing to alter reality to fit her own psychic needs, and that she is completely prepared to exercise the same power by adding another scene to the novel. This reading, however, seems inconsistent with the Briony whose discipline and attention to others has produced the remarkably moving Sections One, Two, and Three of Atonement. Another reading of the two sentences is that they reveal Briony's coming to grips with the falsifying power-that it has long kept her a prisoner and has been her undoing - and that she chooses not to exercise it further, not to falsify beyond what it produced in Sections One, Two, or Three. Why make that choice? Again, there are several possible readings. One is that she makes the choice to stop for a moral reason: she believes that the mix of truth and falsity in her novel comes close enough to meeting a moral standard of acknowledgment and atonement. Another reading is that she ceases simply because her energy is spent, her consciousness is exhausted, and she is ready to stop the mind's wheels. Her back-and-forth travel between truth and falsity has led ultimately to nothing more profound than exhaustion and acceptance of death's imminence.

345. Brian Finney, Briony's Stand Against Oblivion: Ian McEwan's Atonement (2002), http:// web.csulb.edu/ bhfinney/mcewan.html [http://perma.cc/893P-KF3J] ("The novel that we read and that took [Briony's] adult lifetime to write is her attempt to project herself into the feelings of the two characters whose lives her failure of imagination destroyed.").

346. MCEWAN, supra note 335, at 351. 
At the very least, Atonement is a description of that difficult kind of travel. It is what the mind does: navigate, with middling success, the limitations of one's history and the successes, and failures of efforts to become reconciled to oneself. At the same time, it is what the mind can decide to stop doing. In Briony's case, having made a valiant effort (though self-serving in part) to discern her own character and especially the natures of those around her, she closes the book. For her, as for most, the work is left unfinished, but much has been achieved: the mind can rest.

Atonement argues that truth and falsity coexist, with no clear organizing principles. In complex ways, each plays a role in defining the self and clearing a pathway to others. The defamation and statutory falsity cases provide much breathing space for error-not to celebrate it but to make use of it. The legal doctrine covered in this section seeks to create conditions for future truthful speech by accepting a range of false speech. A landscape of varied expression is the projected result, featuring a not necessarily scientific process of sifting and weighing, speaking and counterspeaking, receiving and responding. Fifty-nine years of thinking and weighing got Briony Tallis only so far, but the point is the effort to see across a divide and recognize interests, passions, and fates besides one's own. The fact that Briony at the end does not point to a shining discovered truth but simply closes her final draft and says, "Now I must sleep," does not necessarily mean that she has failed.

\section{TRUTH-SEEKING AND CAMPAIGN FINANCE}

A final question for this Article is: what interest can overcome the truth-seeking value of the First Amendment? As has been noted, that value, for all its strength and subtlety, makes no claim of automatically outweighing other interests or claims. This Article has argued that the truth-seeking value lies behind cautious exploration of the past; it fuels resistance to silencing forces in the present; and it prompts the creation of legal rules to ensure a steady flow of accurate information in the future. Most of the cases examined so far were victories for speech and press and strongly informed by the truth-seeking value, but when is that value overcome? When do the realities of a speech dynamic point in favor of limiting speech rather than protecting it?

Perhaps an answer comes from cases involving campaign finance, where state and federal laws purporting to police the marketplace of ideas and to further truthseeking objectives in the short term come into conflict with the First Amendment's policy of long-term pursuit of truth. This was the scenario in the highly controversial decision in Citizens United v. FEC. ${ }^{347}$ At issue was Section 203 of the Bipartisan Campaign Reform Act of 2002, which criminalized certain political advocacy on an anticorruption rationale. ${ }^{348}$ The Act prohibited unions and

347. Citizens United v. FEC, 558 U.S. 310 (2010)

348. Pub. L. No. 107-155, 116 Stat. 81 (2002). 
corporations, including nonprofits, from spending money from their general treasuries to air messages labeled "electioneering communications"__ broadcast, satellite, or cable advertisements amounting to the functional equivalents of express advocacy for or against a federal candidate. The prohibition spanned sixty days before a general election and thirty days before a primary election, and targeted "independent expenditures"- those not made in coordination or in concert with the federal candidate being supported. The statute, of course, permitted such communications outside of the time restrictions, and it permitted them within the time restrictions if purchased with funds from a "separate segregated fund" (i.e., a political action committee). ${ }^{349}$ Nonetheless, the Court considered the statute a content-based ban on independent spending for political speech, applied strict scrutiny, and ruled, 5-4, that the Act violated the First Amendment.

The Justices in the majority emphasized the problem of disfavoring speech based on a speaker's identity. As the majority saw it, identity could be a proxy for content: "[S]peech restrictions based on the identity of the speaker," wrote Justice Kennedy, "are all too often simply a means to control content." 350 Here, the law sought "to prevent corporations, including small and nonprofit corporations, from presenting both facts and opinions to the public." ${ }^{351}$ Voters thus had less ability "to obtain information from diverse sources in order to determine how to cast their votes." ${ }^{352}$ On this view, the Act was starkly at odds with the constitutional truthseeking value, interfering with the citizen's ability to receive, evaluate, and challenge or support a wide range of political information. ${ }^{353}$

On the other hand, the Act's sponsors, Senators McCain and Feingold, had clearly understood campaign finance reform as aiding the citizen to do those very things. ${ }^{354}$ And at least for a time, the government defended the Act in reliance on an antidistortion interest, citing "the corrosive and distorting effects of immense aggregations of wealth that are accumulated with the help of the corporate form and that have little or no correlation to the public's support for the corporation's political ideas." 355 The antidistortion interest could be seen as a statutory truthseeking value: reducing the potential dominance of corporate speech in the final months of election season, the drafters believed, could only serve the civic interest in accuracy and clarity of whatever social facts had become important in that cycle's public discourse. ${ }^{356}$ Just as Congress in passing the Stolen Valor Act had

349. Citizens United, 558 U.S. at 320-21.

350. Id. at 312 .

351. Id. at 355 .

352. Id. at 341 .

353. Floyd Abrams, who represented Senator McConnell in challenging the statute, argued that BCRA authorized "government censors [to] pars[e] through the content of core political speech in an effort to determine whether it may be published or whether the speaker would be guilty of a crime." ABRAMS, supra note 247, at 309 .

354. John McCain, Reclaiming Our Democracy: The Way Forward, 3 ELECTION L.J. 115, 115 (2004).

355. Citizens United, 558 U.S. at 348.

356. J. Skelly Wright, Politics and the Constitution: Is Money Speech?, 85 YALE L. J. 1001, 1004 
been dissatisfied with the First Amendment's truth-seeking value-with its long view and tolerance of falsity - Congress in enacting BCRA had its own vision of conditions necessary for the search for-and debate about-true facts in the electoral context. But the majority in Citizens United could find no limiting principle in the antidistortion rationale. Those Justices interpreted BCRA's media exemption as an "admission" of the rationale's invalidity, noted that corporations are not monolithic in size or wealth, and rejected the antidistortion rationale as interfering with "the open marketplace of ideas." "357 The majority also noted that even the government had abandoned the antidistortion rationale, opting instead to rely on anticorruption as the governmental interest. ${ }^{358}$

Thus, despite the clear populist appeal and intuitive force of the antidistortion rationale-with its message that well financed corporate speech can drown out other voices and thus impede the voters' process of evaluating both fact and opinion-its rejection was decisive. Part of the problem may have been doubt about its actual meaning. As Professor Hasen has noted, "It is not clear whether the 'drowning out' idea is more about the wealthy buying up all the advertising space on limited media such as television, than it is about large spenders so inundating viewers with a message that viewers are persuaded to vote in a particular way, even if there is contrary advertising from others." 359 Even Justice Stevens's dissent failed to clarify: although he accepted the "drowning out" basis of the rationale, he disclaimed any underlying goal of fostering political equality. ${ }^{360}$ In Professor Hasen's view, Justice Stevens's dissent "offered a hodge-podge of inconsistent understandings" of the rationale. ${ }^{361}$ And even if some version of an antidistortion rationale had appealed to a majority, BCRA's choice of means - a speech banwas foreign to methods associated with the First Amendment's truth-seeking value. The majority's view was that the ban departed from the strategy of encouraging "more speech" and failed to "entrust the people to judge what is true and what is false." "362 This analysis tracked a deep strain of traditional First Amendment thought - that counterspeech is the presumptive methodology of a "free trade in ideas," premised on trust in the citizen's ability to evaluate and act upon information. Perhaps BCRA and the majority shared an overriding vision of a search for functional political truth, but the statute's mistake was to orchestrate the search in top-down fashion. Moving then from anti-distortion to anticorruption, the majority had little trouble declaring that independent expenditures - those without "prearrangement and coordination"- could not be corrupting. At every juncture,

(1976) (noting that one of the "real questions" in debate over campaign finance reform is the extent to which money in U.S. elections "distort[s] the truth-seeking process that lies at the heart of the First Amendment conception").

357. Citizens United, 558 U.S. at 352.

358. Id. at 348 .

359. Richard L. Hasen, Citizens United and the Orphaned Anti-distortion Rationale, 27 GA. ST. U. L. REV. 989, 1003 (2011).

360. Citizens United, 558 U.S. at 970 (Stevens, J., concurring in part, dissenting in part).

361. Hasen, supra note 359, at 997.

362. 558 U.S. at 361,355 . 
the decision strived for consistency with the truth-seeking value, at least in theory.

But, as this Article has argued, the truth-seeking value of the First Amendment is concerned more with facts than with theory-more with actual dynamics than with mental constructs. Sullivan had focused on the practical realities of the common law libel tort and the incentives it created, including its chilling effect. ${ }^{363}$ More recently, the appellate court in 281 Care Comm. emphasized the workings of "false statement" laws, relying on a description by state attorneys general that showed the fraud inducing impact of such laws on the political process. ${ }^{364}$ In Citizens United itself, Justice Kennedy, urging awareness of "the real operations of this legislation" cautioned that "rhetoric ought not obscure reality." "365

The majority's opinion, however, rested on a premise that was arguably at odds with reality then and seems even more so now. That premise was that the corporate expenditures at issue would be "independent," in the sense of uncoordinated with a specific candidate or campaign. On this understanding, the majority ruled that "independent expenditures, including those made by corporations, do not give rise to corruption or the appearance of corruption," that "ingratiation and access are not corruption," and consequently that BCRA's ban was unjustified by any compelling governmental interest. ${ }^{366}$

The problem is that well documented developments show that troubling varieties of coordination clearly do exist, especially with the rise of Super PACs, and that "expenditures meeting the legal definition of 'independent expenditure' are not truly 'independent' in any meaningful sense of the word." 367 Would the Citizens United majority write today with the same conviction if they were confronted with the reality that "independent-expenditure-only political committees" can be run by individuals with extremely close relationships to the candidate in question? ${ }^{368}$ Or if they were confronted with the law's acquiescence to a broad range of collaborative fundraising activities? ${ }^{369}$

If a Super PAC's unrestricted “independent expenditures" are actually illegal contributions to candidates, as they widely appear to be, then the credibility of the system approved by the Court is highly doubtful. The truth-seeking value of the First Amendment, never meant to be absolute and always meant to be reliant on more than presumptions about how the world operates, can offer little protection for such a system. The falsity of "independence" fosters cynicism and estrangement; it echoes the duplicity Scott attributed to the Raj, the half-truths of Ishiguro's Hailsham, and the fraught corridors of the Tallis household, where a central untruth undermines all sustaining relationships.

363. See supra text accompanying notes 304-318.

364. See supra text accompanying notes 336-341.

365. Citizens United, 558 U.S. at 355.

366. Id. at 357,360 .

367. Paul S. Ryan, Two Faulty Assumptions of Citizens United and How to Limit the Damage, 44

U. TOL. L. REV. 583, 585 (2013).

368. Id. at $585-86$.

369. Id. at 587 . 


\section{CONCLUSION}

First Amendment cases do not always invoke the truth-seeking value, but it profoundly affects the vocabulary and direction of many decisions. As Bernard Williams teaches, most of the time the assertions of speakers aim, or purport to aim, at accuracy. With the First Amendment, speech enjoys a generous range of freedom because such breadth enhances the chances that accurate (or at least provisionally accurate) understandings will emerge in the aggregate of public discourse.

As an idea of the First Amendment, the truth-seeking value displays different concerns in different contexts. In some cases, it explores how much of the seemingly unknowable past can be salvaged to assist in current struggles to understand society and politics. In other cases, it demands information about today's facts, too many of which are locked away by agents of public or private power. In yet other cases, it fashions rules for a future flow of information, condoning a complex braiding of truth and falsity, because human experience teaches that there can be roles for both.

As the works of Williams, Murdoch, Scott, Ishiguro, and McEwan reveal, the meanings and effects of truth-seeking are still of vital interest to contemporary thought. In that quintessential American play, Our Town, even the dead argue about what might qualify as true. ${ }^{370}$ The third and final Act is set in a hillside cemetery, where the dead converse while vaguely awaiting a further transformation. One of them, Simon Stimson, who in life had been an alcoholic choir director, remains a figure of bitterness even in the grave. To young Emily, a recent addition to the ranks of the dead who has had the chance to go back among the living only to find the missed connections between humans too painful, Simon inveighs against life, insisting that it was all misery and cruelty. As Simon puts it:

Yes, now you know! Now you know! That's what it was to walk about in a cloud of ignorance, to go up and down trampling on the feelings of those about you, to spend and waste time as though you had a million years, to be always at the mercy of one self-centered passion, or another. Now you know - that's the happy existence you wanted to go back to. Ignorance and blindness. ${ }^{371}$

But another voice answers Simon and sharply differs. This is Mrs. Gibbs, who in life had praised the seeking of experience and all that might be learned from venturing beyond safe precincts, declaring, "It seems to me that once in your life before you die you ought to see a country where they don't talk in English and don't even want to." 372 Now dead, hearing Simon's rant about "ignorance and blindness," Mrs. Gibbs answers, "Simon Stimson, that ain't the whole truth and you know it." 373 She may think he is leaving out the shared nature of the search for

370. See generally Thornton Wilder, OUR Town 109 (Perennial Classics, 2009).

371. Id. at 109.

372. Id. at 20 .

373. Id. at 109 . 
experience and a deliberate kind of growth. Soon the stillness of the place and hour takes over. The world of Act Three is hardly a rambunctious market of ideas, but the exchanges there do reflect the truth-seeking quality of living American talk-its ubiquity, its sometimes harsh insistences on what is or is not, its spectrum of responses, its memories, its silences. 